\title{
Trans-Pacific transport of reactive nitrogen and ozone to Canada during spring
}

\author{
T. W. Walker ${ }^{1, *}$, R. V. Martin ${ }^{1, * *}$, A. van Donkelaar ${ }^{1}$, W. R. Leaitch ${ }^{2}$, A. M. MacDonald ${ }^{2}$, K. G. Anlauf ${ }^{2}$, R. C. Cohen $^{3}$, \\ T. H. Bertram ${ }^{4}$, L. G. Huey ${ }^{5}$, M. A. Avery ${ }^{6}$, A. J. Weinheimer ${ }^{7}$, F. M. Flocke ${ }^{7}$, D. W. Tarasick ${ }^{2}$, A. M. Thompson ${ }^{8}$, \\ D. G. Streets ${ }^{9}$, and X. Liu ${ }^{10}$
}

${ }^{1}$ Department of Physics \& Atmospheric Science, Dalhousie University, Halifax, Nova Scotia, Canada

${ }^{2}$ Environment Canada, Downsview, Ontario, Canada

${ }^{3}$ College of Chemistry, University of California at Berkeley, Berkeley, California, USA

${ }^{4}$ Department of Chemistry \& Biochemistry, University of California at San Diego, San Diego, California, USA

${ }^{5}$ School of Earth \& Atmospheric Sciences, Georgia Institute of Technology, Atlanta, GA, USA

${ }^{6}$ Atmospheric Sciences Division, NASA Langley Research Center, Hampton, Virginia, USA

${ }^{7}$ National Center for Atmospheric Research, Boulder, Colorado, USA

${ }^{8}$ Meteorology Department, Pennsylvania State University, University Park, Pennsylvania, USA

${ }^{9}$ Decision and Information Sciences Division, Argonne National Laboratory, Argonne, IL, USA

${ }^{10}$ University of Baltimore County (UMBC), Goddard Earth Sciences and Technology (GEST), Baltimore, Maryland, USA

*now at: Department of Physics, University of Toronto, Toronto, Ontario, Canada

**also at: Harvard-Smithsonian Center for Astrophysics, Cambridge, Massachusetts, USA

Received: 13 January 2010 - Published in Atmos. Chem. Phys. Discuss.: 7 April 2010

Revised: 31 August 2010 - Accepted: 1 September 2010 - Published: 7 September 2010

\begin{abstract}
We interpret observations from the Intercontinental Chemical Transport Experiment, Phase B (INTEX-B) in spring 2006 using a global chemical transport model (GEOSChem) to evaluate sensitivities of the free troposphere above the North Pacific Ocean and North America to Asian anthropogenic emissions. We develop a method to use satellite observations of tropospheric $\mathrm{NO}_{2}$ columns to provide timely estimates of trends in $\mathrm{NO}_{\mathrm{x}}$ emissions. $\mathrm{NO}_{\mathrm{x}}$ emissions increased by 33\% for China and 29\% for East Asia from 2003 to 2006. We examine measurements from three aircraft platforms from the INTEX-B campaign, including a Canadian Cessna taking vertical profiles of ozone near Whistler Peak. The contribution to the mean simulated ozone profiles over Whistler below $5.5 \mathrm{~km}$ is at least $7.2 \mathrm{ppbv}$ for Asian anthropogenic emissions and at least $3.5 \mathrm{ppbv}$ for global lightning $\mathrm{NO}_{\mathrm{x}}$ emissions. Tropospheric ozone columns from OMI exhibit a broad Asian outflow plume across the Pacific, which is reproduced by simulation. Mean modelled sensitivities of Pacific $\left(30^{\circ} \mathrm{N}-60^{\circ} \mathrm{N}\right)$ tropospheric ozone columns are
\end{abstract}

at least 4.6DU for Asian anthropogenic emissions and at least 3.3 DU for lightning, as determined by simulations excluding either source. Enhancements of ozone over Canada from Asian anthropogenic emissions reflect a combination of trans-Pacific transport of ozone produced over Asia, and ozone produced in the eastern Pacific through decomposition of peroxyacetyl nitrates (PANs). A sensitivity study decoupling PANs globally from the model's chemical mechanism establishes that PANs increase ozone production by removing $\mathrm{NO}_{\mathrm{x}}$ from regions of low ozone production efficiency (OPE) and injecting it into regions with higher OPE, resulting in a global increase in ozone production by $2 \%$ in spring 2006. PANs contribute up to $4 \mathrm{ppbv}$ to surface springtime ozone concentrations in western Canada. Ozone production due to PAN transport is greatest in the eastern Pacific; commonly occurring transport patterns advect this ozone northeastward into Canada. Transport events observed by the aircraft confirm that polluted airmasses were advected in this way. 


\section{Introduction}

Long-range transport of reactive nitrogen and ozone pollution from Asia is a growing concern in light of rapid economic and industrial growth in Asia (Parrish et al., 1992; Jacob et al., 1999; Richter et al., 2005). The Intercontinental Transport Experiment, Phase B (INTEX-B) campaign characterizes this transport with measurement of gases and aerosols from aircraft and ozonesondes over the North Pacific Ocean and western North America in April-May 2006, along with concurrent observations from satellite instruments (Singh et al., 2009). Interpretation of such measurements requires an understanding of the chemical and physical mechanisms involved in long-range transport. A 3-D global chemical transport model can be used to develop this understanding, by probing the sensitivities of the observations to emission sources and chemical mechanisms.

Previous analyses of long-range transport to Canada have focused on aerosols, chlorinated organic pollutants, and heavy metals (Welch et al., 1991; Bailey et al., 2000; McKendry et al., 2001; Gong and Barrie, 2003; van Donkelaar et al., 2008). The INTEX-B campaign included regular aircraft profiles from a Cessna-207 in western Canada, as well as intensive ozonesonde releases from several Canadian sites, which we interpret in context of the broader INTEX-B campaign to understand the processes and impacts of ozone pollution transport into Canada. To assess these impacts, we study the chemistry of ozone formation, as well as emissions of precursor gases from natural and anthropogenic sources. Remote sensing observations are included to quantitatively constrain and validate precursor emissions.

Tropospheric ozone is a major greenhouse gas, contributes to atmospheric oxidation, and is toxic to biota. Production of ozone in the remote troposphere is limited primarily by the concentration of $\mathrm{NO}_{\mathrm{x}}\left(\mathrm{NO}_{\mathrm{x}}=\mathrm{NO}_{2}+\mathrm{NO}\right)$ (Liu et al., 1987). Although the short chemical lifetime of $\mathrm{NO}_{\mathrm{x}}$ inhibits its direct transport from Asian sources to the remote Pacific, $\mathrm{NO}_{\mathrm{x}}$ can be redistributed through the injection of peroxyacyl nitrates (PAN = peroxyacetyl nitrate and its structural analogues) from polluted areas into the upper troposphere where cold temperatures allow PANs to persist for weeks. This process removes reactive nitrogen from high emission regions and redistributes it to remote areas (Moxim et al., 1996). Upon subsidence of PANs in these remote areas, $\mathrm{NO}_{\mathrm{x}}$ is generated, triggering ozone production. There is growing evidence that increasing Asian emissions are impacting western North American ozone (Parrish et al., 2009; Cooper et al., 2010).

Previous studies of Asian outflow and pollution transport in the Pacific using aircraft measurements such as TRACE-P (Browell et al., 2003; Heald et al., 2003; Talbot et al., 2003) and ITCT-2K2 (Hudman et al., 2004) have established the above pathway as a method for ozone production in the remote Pacific. Studies of Asian outflow suggest that warm conveyor belt (WCB) airstreams within extra-tropical cy- clones inject pollution into the free troposphere (Bey et al., 2001a; Cooper et al., 2004; Li et al., 2005), and that PANs dominate the $\mathrm{NO}_{\mathrm{y}}$ budget $\left(\mathrm{NO}_{\mathrm{y}}=\mathrm{NO}_{\mathrm{x}}+\mathrm{HNO}_{3}+\mathrm{PANs}+\right.$ $\mathrm{N}_{2} \mathrm{O}_{5}+\mathrm{HNO}_{4}$ ) in the outflow to the free troposphere (Koike et al., 2003; Miyazaki et al., 2003). Modelling studies of pollution transport (Berntsen et al., 1996, 1999; Jacob et al., 1999; Li et al., 2005) indicate that an increase in Asian emissions significantly enhances pollutant concentrations in the eastern Pacific and over North America. Furthermore, there is evidence that inflow of ozone from the marine boundary layer to western North America has been increasing (Parrish et al., 2009). Despite recent works that examine the impact of various sources to ozone over Asia and the North Pacific Ocean (Zhang et al., 2008, 2009a), additional analysis is needed to disentangle the relative roles of ozone production near Asia and subsequent long-range transport, and its in situ production near North America caused by either longrange transport of long-lived precursor gases such as PANs, or by direct emission of $\mathrm{NO}_{\mathrm{x}}$ from natural sources such as lightning.

Lightning $\mathrm{NO}_{\mathrm{x}}$ emissions and consequent in situ ozone production were found to have a surprising impact in the upper troposphere over North America during the Intercontinental Chemical Transport Experiment, Phase A (INTEX-A) (Cooper et al., 2006; Hudman et al., 2007; Thompson et al., 2007) and INTEX-B (Cooper et al., 2007; Thompson et al., 2008) campaigns. Lightning also makes an important contribution to Asian outflow and ozone columns over the North Pacific Ocean (Liu et al., 2002). We examine the contribution of lightning to ozone and reactive nitrogen observations over the North Pacific Ocean during INTEX-B.

Satellite remote sensing observations of trace gases provide timely global information that can be used to evaluate and improve emission inventories (Martin et al., 2003a; Palmer et al., 2003; Jaeglé et al., 2005), to examine emissions trends (Richter et al., 2005; Zhang et al., 2007), and also to understand transport pathways (Heald et al., 2003; Allen et al., 2004; Heald et al., 2006; Zhang et al., 2008). We use observations of trends in tropospheric $\mathrm{NO}_{2}$ columns from the SCanning Imaging Absorption SpectroMeter for Atmospheric CHartographY instrument (SCIAMACHY) from 2003-2006 to construct a top-down anthropogenic $\mathrm{NO}_{\mathrm{x}}$ emission inventory for 2006. This inventory is evaluated by comparison with a timely bottom-up inventory and with tropospheric $\mathrm{NO}_{2}$ columns from SCIAMACHY. Simulated ozone columns over the North Pacific Ocean are compared with a retrieval of tropospheric ozone columns using OMI (Liu et al., 2010).

The attribution of pollution to a particular source region through the use of observations alone is confounded by the interactions between export, non-linear chemical processing and dilution during transport, and local mixing near the observation (Fiore et al., 2009). Global chemical transport models therefore provide integral insights in the study of long-range pollution transport, as further evidenced by the 


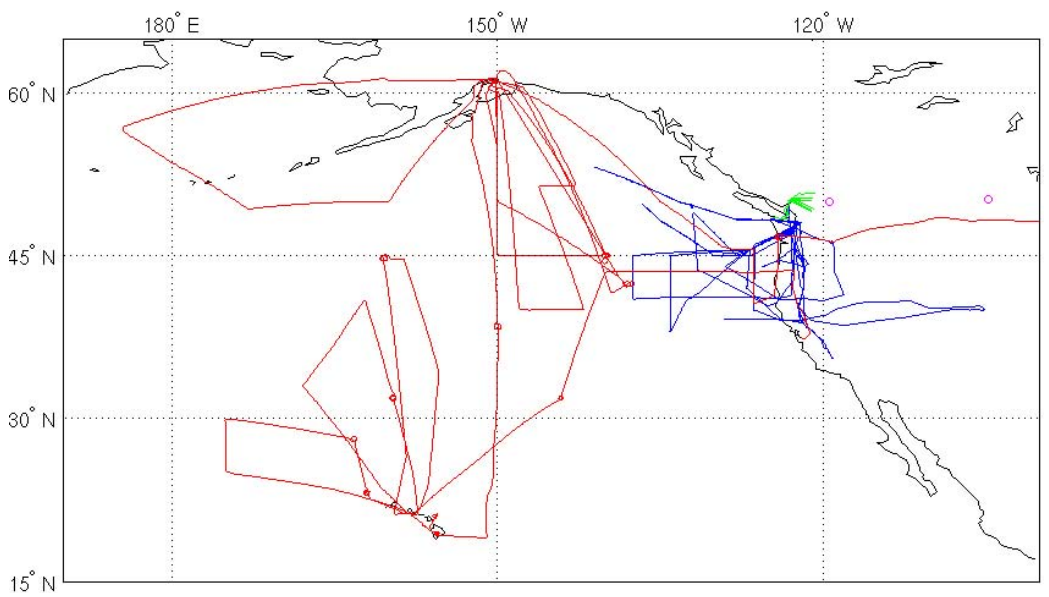

Fig. 1. Flight tracks for the NASA DC-8 (red), NCAR C-130 (blue), and Canadian Cessna (green) aircraft platforms during INTEX-B between April 17 and May 17, 2006. Also plotted are the IONS ozonesonde sites (magenta circles) at Kelowna, BC and Bratt's Lake, SK.

numerous studies that employ them (Berntsen et al., 1996, 1999; Jacob et al., 1999; Heald et al., 2003; Hudman et al., 2004; Li et al., 2005). One potential issue in the simulation of long-range transport is the degree to which photochemical processing and mixing are represented. The logarithm of the ratio of two hydrocarbons with different reactivities provides a measure of photochemical processing and the age of an airmass (Roberts et al., 1984). Parrish et al. $(1992,2004)$ found that the ratio of propane to ethane remains remarkably robust as an indicator of air mass age over several e-folding lifetimes. The INTEX-B observations of these alkanes provide a test for global simulations.

We use the GEOS-Chem model to interpret aircraft measurements of $\mathrm{O}_{3}$ and reactive nitrogen from the Pacific phase of INTEX-B and from satellite and ozonesonde observations during the same time period. We develop a baseline simulation that reproduces the aircraft mean vertical profiles of ozone and reactive nitrogen, and use a set of sensitivity simulations to probe the dependence of the signal at the aircraft and sonde locations to various $\mathrm{NO}_{\mathrm{x}}$ emissions sources and chemical sensitivities. A transport event observed by the aircraft on 4-5 May 2006 is examined in detail as evidence of a transport pathway for ozone pollution due to Asia sources entering western Canada.

\section{Overview of data sets}

\subsection{Aircraft data}

INTEX-B included an intensive aircraft measurement campaign over western North America and the North Pacific Ocean during April and May 2006 (Singh et al., 2009). We use data from three of the airborne platforms during the $\mathrm{Pa}$ cific phase of the mission: the NASA DC- 8 which flew 4 flights out of Hilo, Hawaii and 5 flights out of Anchorage,
Alaska; the NCAR C-130 which flew 12 flights out of Seattle, Washington; and a Canadian Cessna-207 which flew 33 flights out of Pemberton, British Columbia. Flight tracks for these platforms are shown in Fig. 1. The DC-8 and C-130 flew varied flight paths over a large domain, relying on chemical forecasts to identify potentially interesting airmasses. As described by Leaitch et al. (2009), the Cessna flew regular vertical profiles over the nearby ground measurement station at Whistler Peak to facilitate the interpretation of the measurements, to provide context for the Whistler summit station, and to accomodate the shorter range of the Cessna. Singh et al. (2009) describe the instrumentation on all three aircraft platforms.

Consistency of the Cessna ozone measurements with the other platforms is of interest. Figure 2 shows flight tracks and vertical ozone profiles from the two intercomparison flights between the C-130 and Cessna platforms. Points used in the vertical comparison include only measurements within $0.3^{\circ}$ latitude and longitude that sampled at the same altitude within 20 minutes of one another. On May 3, the C-130 flew to Whistler to compare with the Cessna at its habitual profiling location. Both aircraft flew profiles over the vertical range of the Cessna within a half hour, although the C-130 did not descend as low as the Cessna. Data from this comparison are shown in the top row of Fig. 2, showing fair agreement throughout the profile. The two craft flew a second intercomparison (bottom row of Fig. 2) on May 9 at the Canada-US border. The aircraft only came within $15 \mathrm{~km}$ of one another and attempted vertical profiles as they separated; however, during these profiles, relative humidity measurements indicate that the two planes encountered different airmasses, and so the majority of the data from these profiles are excluded from this comparison. Ozone concentrations measured by the $\mathrm{C}-130$ exceed those from the Cessna by $4 \mathrm{ppbv}$ on average, the bias increasing with altitude. Chen et al. (2007) and Kleb et al. (2010) found that the DC-8 and 

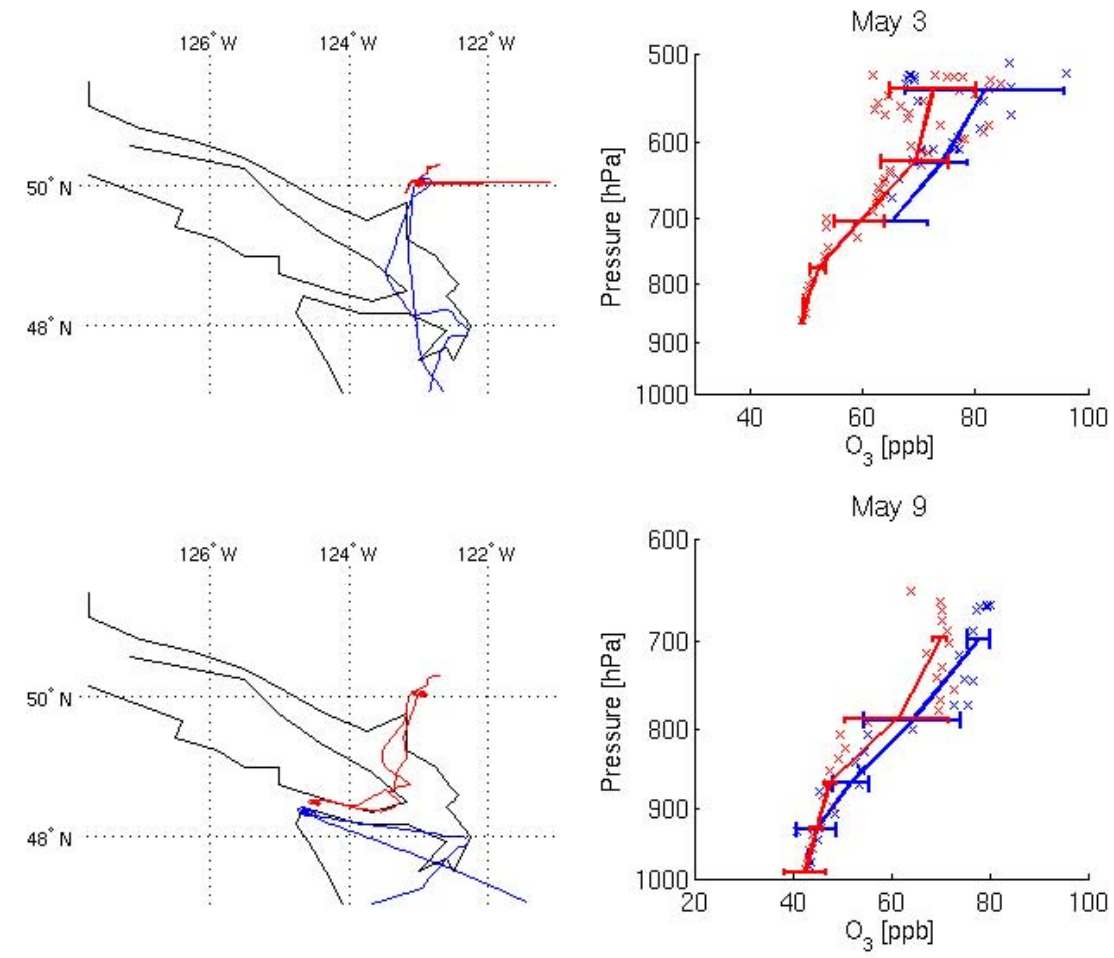

Fig. 2. Flight tracks and vertical mean profiles of ozone measurements during the two intercomparison flights between the C-130 (shown in blue) and the Cessna (in red). Top panels show the May 3 flights; bottom panels show the May 9 flights. Crosses indicate 1-minute mean measured values of ozone on each platform. Data are filtered to include only points where the two platforms flew within $0.3^{\circ}$ latitude and longitude of one another.

the C-130 ozone are within 5 ppbv, measurements from the $\mathrm{C}-130$ being $2 \%$ higher on average. The intercomparison between the various aerosol instruments is described in van Donkelaar et al. (2008).

For subsequent analysis, the aircraft data were filtered for stratospheric air and for fresh pollution plumes following Hudman et al. (2007). The stratospheric filter used a threshold $\mathrm{O}_{3}$ : $\mathrm{CO}$ ratio of 1.25 , which removed $0.2 \%$ of the $\mathrm{C}-130$ data and $6.5 \%$ of the DC- 8 data. The filter for fresh pollution plumes removed points with a $\mathrm{NO}_{\mathrm{x}}: \mathrm{NO}_{\mathrm{y}}$ ratio in excess of 0.4 or a $\mathrm{NO}_{\mathrm{x}}$ concentration greater than $0.5 \mathrm{ppbv}$, removing $3.6 \%$ of the C- 130 data and $1.1 \%$ of the DC- 8 data. Sufficient reactive nitrogen and $\mathrm{CO}$ measurements were unavailable for the Cessna, so these data are unfiltered. After these filters were applied, the aircraft data were averaged onto the horizontal and vertical resolution of the GEOS-Chem model.

\subsection{Remote sensing data}

The Ozone Monitoring Instrument (OMI) on the Aura satellite is a UV-visible spectrometer viewing in nadir (Levelt et al., 2006). Aura was launched in July 2004 into a nearpolar sun-synchronous orbit with a local equator-crossing time of 13:45. OMI achieves daily global observations of solar backscatter in the early afternoon atmosphere at a spatial resolution of up to $13 \mathrm{~km} \times 24 \mathrm{~km}$ at nadir. The spectra (from $270 \mathrm{~nm}$ to $500 \mathrm{~nm}$ ) gathered by OMI permit the retrieval of several important trace gases, including $\mathrm{O}_{3}$, which is used here for 2006.

Liu et al. (2010) performed ozone profile retrievals using an optimal estimation technique to fit the calibrated radiances in the Hartley and Huggins bands $(270-330 \mathrm{~nm})$ as measured by OMI. The retrieval produced partial ozone column densities in 24 layers from the surface to about $60 \mathrm{~km}$. The retrieval has 6-7 degrees of freedom for signal overall, up to 1.5 of which are in the troposphere. We only use retrievals with at least 0.5 degrees of freedom in the troposphere to allow the separation of a tropospheric ozone column. For solar zenith angles below $80^{\circ}$, the precision of the retrieved tropospheric ozone column is $0.7-3 \mathrm{DU}$ with an error of $2-5 \mathrm{DU}$ (4-20\%), increasing rapidly at greater solar zenith angles. Daily data are averaged here over April-May 2006.

We also use $\mathrm{NO}_{2}$ tropospheric columns obtained using observations of solar backscatter from the SCanning Imaging Absorption spectroMeter for Atmospheric CHartographY (SCIAMACHY) satellite instrument (Bovensmann et al., 1999). The SCIAMACHY instrument observes the atmosphere in nadir from the ENVISAT satellite, which was launched in March 2002 into a sun-synchronous orbit with a 10:00 local equator-crossing time. SCIAMACHY achieves 
global coverage in 6 days, at a typical horizontal resolution of $30 \mathrm{~km}$ along track and $60 \mathrm{~km}$ across track.

The tropospheric column $\mathrm{NO}_{2}$ retrieval begins with a spectral fit at visible wavelengths to obtain slant columns. The stratospheric column is then removed, and the remaining slant columns are converted to tropospheric vertical columns using an air mass factor calculation using vertical profiles from GEOS-Chem simulations. Detailed retrieval descriptions can be found in Martin et al. (2006) with updates in Kaynak et al. (2008). The retrieval uncertainty for SCIAMACHY monthly mean $\mathrm{NO}_{2}$ tropospheric columns is $\pm(5 \times$ $10^{14}$ moleccm $^{-2}+30 \%$ ) for cloud-filtered scenes (Martin et al., 2006).

\subsection{Ozonesonde data}

Ozonesonde data from the INTEX-B Ozonesonde Network Study 2006 (IONS-06) over North America during April and May 2006 are used from release points in Kelowna, British Columbia (26 sondes), and Bratt's Lake, Saskatchewan (29 sondes) (Thompson et al., 2008). The high measurement frequency at these two sites, and their proximity to the Cessna aircraft flight tracks, makes them particularly valuable sites for this work.

The WMO thermal tropopause is defined for each sounding (WMO, 1966). For pressures below $500 \mathrm{hPa}$, the thermal tropopause is defined as the lowest point with respect to altitude where the lapse rate decreases to $2 \mathrm{Kkm}^{-1}$. The average lapse rate to any point within the next higher two kilometers may not exceed $2 \mathrm{Kkm}^{-1}$, and the sounding must extend at least $2 \mathrm{~km}$ above that point. The mean tropopause pressure for the Kelowna sondes was $272 \mathrm{hPa}$, and that for Bratt's Lake was $241 \mathrm{hPa}$. The ozonesonde profiles at each location are averaged at altitudes below the WMO tropopause calculated for each sounding.

\subsection{Model description}

In order to interpret the measurements, we employ the GEOS-Chem global chemical transport model, version 704-10 (http://www.geos-chem.org/) to simulate tropospheric chemistry and transport, with some modifications as described below. Transport in the model is driven by GEOS4 assimilated meteorological fields from the NASA Global Modeling and Assimilation Office, which have 6-h (3$\mathrm{h}$ for surface fields and mixing depths) temporal resolution. GEOS-Chem includes a detailed $\mathrm{NO}_{\mathrm{x}}-\mathrm{O}_{\mathrm{x}}$-hydrocarbon chemistry mechanism that was first described by Bey et al. (2001b) with initial updates by Fiore et al. (2002), Martin et al. (2002, 2003b), and Evans and Jacob (2005). It also includes a simulation of aerosols and their precursors (Park et al., 2004) that is coupled to the gas-phase chemistry simulation through effects on photolysis frequencies (Martin et al., 2003b) as well as through the formation of sulphate and nitrate, partitioning of total inorganic nitrate into $\mathrm{HNO}_{3}$ and $\mathrm{NO}_{3}^{-}$, and heterogeneous chemistry (Jacob, 2000). Cross-tropopause ozone transport is prescribed by the synthetic ozone method (McLinden et al., 2000), while the cross-tropopause $\mathrm{NO}_{\mathrm{y}}$ flux is calculated from $\mathrm{N}_{2} \mathrm{O}$ oxidation in the model stratosphere. Global annual net stratospheric fluxes are $500 \mathrm{TgO}_{3} \mathrm{yr}^{-1}$ and $0.5 \mathrm{TgNyr}^{-1}$. The model is run at a horizontal resolution of $2^{\circ} \times 2.5^{\circ}$, with 55 vertical levels, the lowest five of which are centered at approximately $170 \mathrm{~m}, 360 \mathrm{~m}, 722 \mathrm{~m}, 1299 \mathrm{~m}$, and $2081 \mathrm{~m}$.

In the standard model, anthropogenic emissions are obtained from the Global Emission Inventory Activity (GEIA) bottom-up inventory. This global inventory is overwritten with regional inventories over North America (EPA NEI99), and East Asia (Streets et al., 2003, 2006; Zhang et al., $2009 \mathrm{~b})$. The global distribution of lightning $\mathrm{NO}_{\mathrm{x}}$ emissions is calculated according to the scheme of Price and Rind (1992), and then locally rescaled here using seasonal mean flash rates from the Optical Transient Detector and Lightning Imaging Sensor (OTD-LIS), following Sauvage et al. (2007). Lightning emissions are distributed vertically according to Pickering et al. (1998).

The GEOS-Chem model has been applied to a variety of studies, including several involving continental outflow (Bey et al., 2001a; Li et al., 2004; Park et al., 2006; Hudman et al., 2009; Zhang et al., 2010) and long-range transport (Jacob et al., 1999; Heald et al., 2003, 2006; Hudman et al., 2004, 2007; Guerova et al., 2006; Fairlie et al., 2007; van Donkelaar et al., 2008; Zhang et al., 2008; Fiore et al., 2009; Wu et al., 2009; Fisher et al., 2010; Nam et al., 2010; Rastigeyev et al., 2010). Simulations of ozone generally agree with monthly mean ozonesonde measurements over North America to within $10 \mathrm{ppbv}$ (Bey et al., 2001b), and simulations of reactive nitrogen are generally within $30 \%$ of measured values (Martin et al., 2006; Hudman et al., 2007; Zhang et al., 2008).

We construct a baseline simulation that incorporates updates to anthropogenic and natural emissions. A recent emission inventory for the year 2006 is implemented for East Asia for $\mathrm{NO}_{\mathrm{x}}, \mathrm{CO}$, and VOC's (Zhang et al., 2009b). Reactive NMVOC emissions from biomass burning are increased here by a factor of 5, following Fu et al. (2007) in order to capture satellite-observed isoprene emissions behaviour. Lightning $\mathrm{NO}_{\mathrm{x}}$ emissions are rescaled here using seasonal mean flash rates from the Optical Transient Detector and Lightning Imaging Sensor (OTD-LIS), following Sauvage et al. (2007). This produces a global flash rate of 44 flashes/s, with $22 \%$ of flashes at midlatitudes (Christian et al., 2003). Application of a midlatitude NO yield of 360 moles/flash (Ott et al., 2007) produces a midlatitude source of $1.5 \mathrm{TgNyr}^{-1}$, consistent with constraints inferred from aircraft $\mathrm{NO}_{\mathrm{x}}$ observations (Martin et al., 2006; Hudman et al., 2007). A tropical NO yield of 280 moles/flash produces a global source of $6 \mathrm{TgNyr}^{-1}$, as constrained by in situ and satellite observations of trace gases (Martin et al., 2007; Sauvage et al., 2007). These NO yields/flash differ from those in Hudman 
Table 1. Description of baseline and sensitivity simulations performed with the GEOS-Chem model.

\begin{tabular}{cl}
\hline Simulation & Description \\
\hline Baseline & $\begin{array}{l}\text { version 7-04-10; 2006 Asian anthropogenic emissions (Zhang et al., 2009b); lightning } \\
\text { scaled by seasonal OTD-LIS (Sauvage et al., 2007) and mid-latitude source scaled to } \\
\text { 1.6 } \mathrm{Tg} \mathrm{yr}^{-1} \text { (Martin et al., 2006); biomass burning reactive NMVOC source increased } \\
\text { by factor of 5 (Fu et al., 2007) }\end{array}$ \\
\hline Scaled 2006 & $\begin{array}{l}\text { baseline emissions, substituting scaled anthropogenic } \mathrm{NO}_{\mathrm{x}} \text { emissions for those from } \\
\text { Zhang et al. (2009b) over East Asia }\end{array}$ \\
\hline No lightning & baseline emissions, with lightning $\mathrm{NO}_{\mathrm{x}}$ emissions off \\
\hline No Asia & baseline emissions, with Asian anthropogenic emissions off \\
\hline No PAN & baseline emissions, with peroxyacyl nitrates removed from chemical mechanism \\
\hline
\end{tabular}

et al. (2007) due to our use of the observed OTD-LIS flash distribution. Latitudinal gradients in vertical wind shear may be responsible for the greater NO yield at midlatitudes than in the tropics (Huntrieser et al., 2008).

Table 1 describes the baseline simulation and four sensitivity simulations that were also conducted. The "Scaled 2006" simulation uses the scaled anthropogenic $\mathrm{NO}_{\mathrm{x}}$ inventory derived in the next section. The "no lightning" and "no Asia" simulations exclude the global lightning $\mathrm{NO}_{\mathrm{x}}$ or Asian anthropogenic emissions, respectively, and are used in order to evaluate these sources' contributions relative to the baseline simulation. Similarly, the "no PAN" simulation was implemented by removing any reactions involving peroxyacyl nitrates from the chemical mechanism, following Moxim et al. (1996). This method permits the evaluation of direct transport of ozone from Asia compared to transport that involves the conversion of $\mathrm{NO}_{\mathrm{x}}$ into PANs for transport in the free troposphere. All simulations were allowed to spin up for 9 months.

\section{Origins of Asian outflow}

\subsection{Estimate of Emissions}

Bottom-up emissions inventories generally take years to compile and are released infrequently. Such delays can be especially problematic in regions where emissions are changing rapidly, such as in East Asia. However, satellite observations can provide timely information with near global coverage. Although we have implemented a recent bottom-up inventory for 2006 developed for the INTEX-B period (Zhang et al., 2009b), we present here an alternative method of obtaining an estimate of emissions from trends in satellite observations that was developed before the release of this recent inventory. We scrutinize the scaling method by comparison with the bottom-up inventory of Zhang et al. (2009b) and with satellite observations of tropospheric $\mathrm{NO}_{2}$ columns. Obtaining emissions estimates from satellite trends could be useful in cases where an accurate bottom-up inventory is unavailable, or as a first guess at emissions in an area experiencing rapid change.

Most previous top-down estimates of $\mathrm{NO}_{\mathrm{x}}$ emissions have used observations for a specific time period to constrain emissions for that time period (Martin et al., 2003a; Jaeglé et al., 2005; Müller and Stavrakou, 2005; Konovalov et al., 2006; Zhang et al., 2008). A challenge with such an approach is that the a priori inventory may be out of date (Martin et al., 2006), or that the result is sensitive to retrieval biases (van Noije et al., 2006; Lamsal et al., 2010a). The scaling approach presented here has the advantages of beginning with observations for the same time period as the a priori inventory, and potentially lower retrieval errors in inferring a trend than in using a specific year due to cancellation of systematic errors in the retrievals.

We begin with a bottom-up East Asian anthropogenic $\mathrm{NO}_{\mathrm{x}}$ emissions inventory for the year 2000 (the TRACE-P inventory, from Streets et al. (2003) with updates in Streets et al. (2006)). This inventory is first scaled forward to 2003 based on trends in fossil fuel consumption by country, as described in van Donkelaar et al. (2008). $\mathrm{NO}_{\mathrm{x}}$ emissions over East Asia increase from a total $6.9 \mathrm{TgNyr}^{-1}$ in 2000 to $8.4 \mathrm{TgNyr}^{-1}$ in 2003. This scaling is standard practice in GEOS-Chem; however, the fuel consumption statistics lag by several years. We use $\mathrm{NO}_{2}$ column observations during spring from SCIAMACHY during the intervening years (2003-2006) to calculate a trend for each model grid cell. A GEOS-Chem simulation in which East Asian surface emissions are perturbed by $30 \%$ establishes the relationship between surface $\mathrm{NO}_{\mathrm{x}}$ emissions and $\mathrm{NO}_{2}$ columns:

$$
\frac{\mathrm{E}(\text { perturb })}{\mathrm{E}(\text { base })}=\beta \frac{\Omega_{\mathrm{NO}_{2}}(\text { perturb })}{\Omega_{\mathrm{NO}_{2}} \text { (base) }}
$$

where $\Omega_{\mathrm{NO}_{2}}$ denotes column $\mathrm{NO}_{2}$ and $\mathrm{E}$ denotes emissions in the perturbed and baseline runs. The factor $\beta$ represents the local factors that affect the relationship between $\mathrm{NO}_{\mathrm{x}}$ emissions and the $\mathrm{NO}_{2}$ column, in a similar fashion to the 


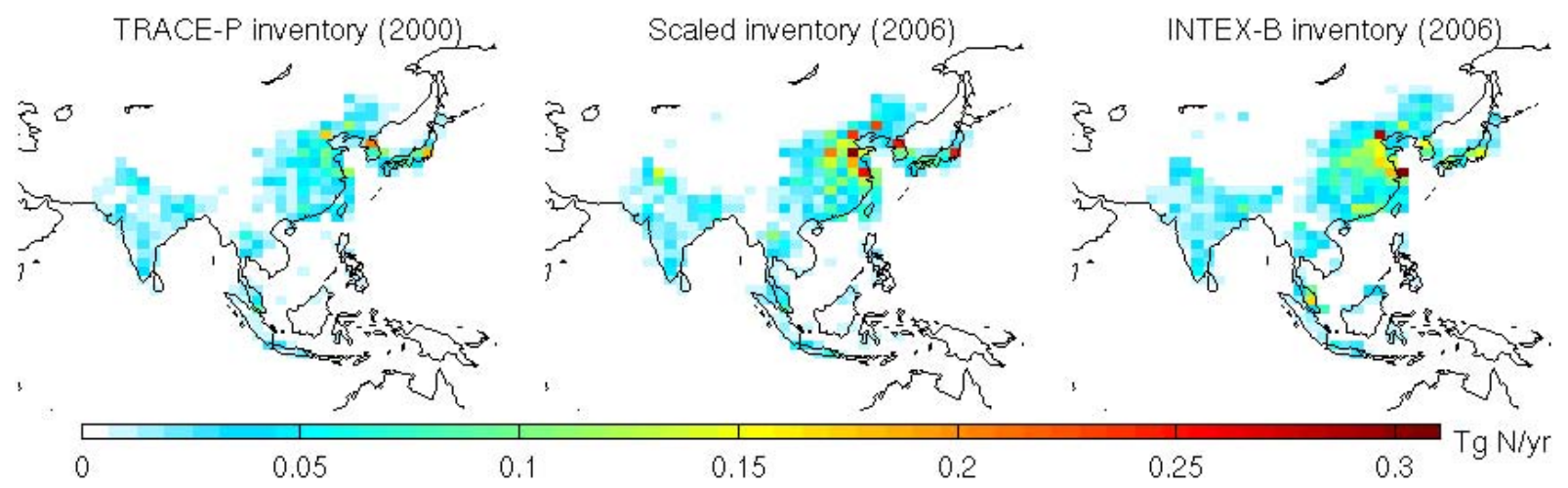

Fig. 3. Development of the Asian anthropogenic $\mathrm{NO}_{\mathrm{x}}$ emission inventory for the baseline simulation. The left panel shows the standard GEOS-Chem regional inventory for East Asia, compiled for TRACE-P by Streets et al. (2003). The center panel contains the emission inventory after applying a two-stage scaling process using ratios of annual fuel consumption from 2000 to 2003 , as well as a linear regression of springtime tropospheric $\mathrm{NO}_{2}$ columns from SCIAMACHY from 2003 to 2006 . The right panel displays a recent $\mathrm{NO}_{\mathrm{x}}$ emission inventory compiled by Zhang et al. (2009b).
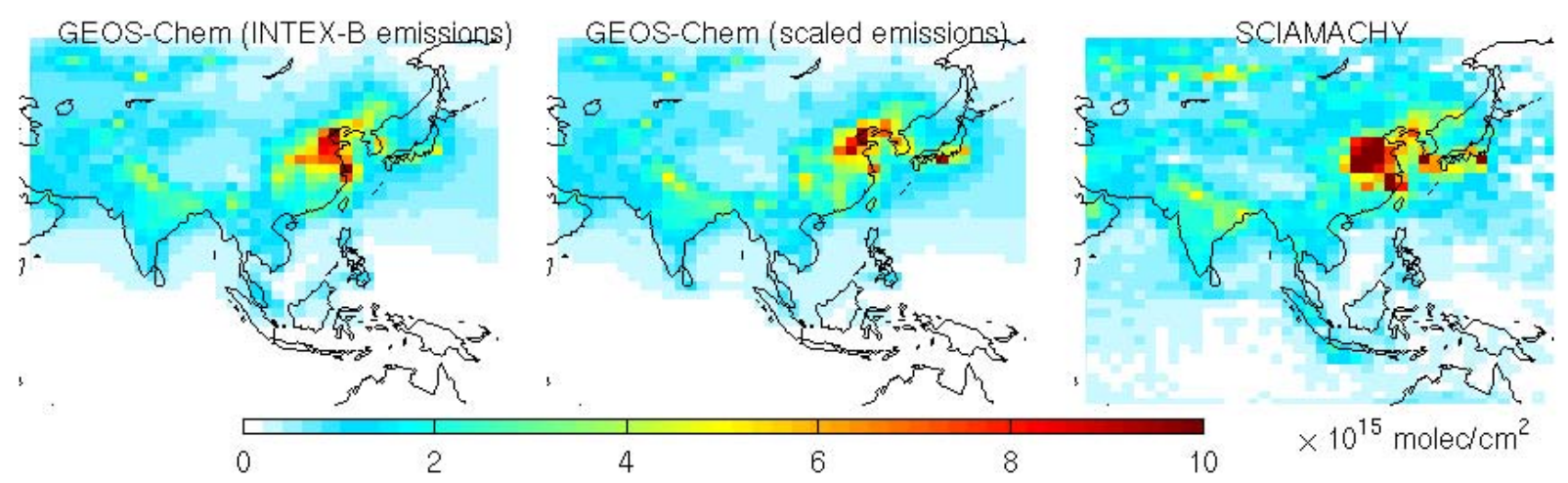

Fig. 4. Simulated and observed mean tropospheric $\mathrm{NO}_{2}$ columns for April-May 2006. The left panel shows simulated columns from the baseline simulation, sampled at the satellite overpass times for SCIAMACHY. The central panel shows the same quantity for the GEOSChem simulation using the scaled emissions. The right panel shows $\mathrm{NO}_{2}$ columns retrieved from the SCIAMACHY satellite instrument.

variable $\alpha$ used to infer top-down emissions (E) by Martin et al. (2003a):

$$
E=\alpha \cdot \Omega
$$

However, $\alpha$ has units of $\mathrm{s}^{-1}$ and describes the direct relationship between $\mathrm{NO}_{2}$ columns and $\mathrm{NO}_{\mathrm{x}}$ emissions. $\beta$ is a unitless trend factor that describes how a change in $\mathrm{NO}_{\mathrm{x}}$ emissions affects a change in $\mathrm{NO}_{2}$ columns. The factor $\beta$ is then used to infer the emissions trend between 2003 and 2006 from SCIAMACHY observed $\mathrm{NO}_{2}$ columns. The linear trend in the derived emissions during these years is then used to scale the 2003 inventory forward to 2006 . The use of a linear trend reduces sensitivity of the trend to anomalous events such as from biomass burning. Lamsal et al. (2010b) further discuss $\beta$ and extend this approach globally. These calculations are performed at the model resolution over the East Asian region.
The center panel of Fig. 3 shows the scaled inventory, which exhibits an increase in anthropogenic $\mathrm{NO}_{\mathrm{x}}$ emissions by $58 \%$ over the East Asian region compared with the 2000 inventory (shown in the left panel). The increase over China is $84 \%$. The bottom-up inventory of Zhang et al. (2007) is displayed in the rightmost panel of Fig. 3. This inventory increases East Asian $\mathrm{NO}_{\mathrm{x}}$ emissions by $62 \%$ compared with the 2000 inventory, and emissions in China by $98 \%$. Zhang et al. (2007) found good agreement between trends in satellite and bottom-up inventories during the summer months, but discrepancies during the winter when emissions were at their annual peak. The close agreement here indicates that the trends in spring are also comparable between satellite and bottom-up inventories. 


\subsection{Evaluation of simulation}

Remote sensing observations of $\mathrm{NO}_{2}$ tropospheric columns were used to evaluate the changes to $\mathrm{NO}_{\mathrm{x}}$ emissions implemented for the baseline simulation. The left panel of Fig. 4 shows tropospheric $\mathrm{NO}_{2}$ columns from the baseline simulation averaged over April-May 2006. The model is sampled at the satellite overpass time for SCIAMACHY. A pronounced maximum is apparent from anthropogenic emissions over eastern China. We evaluate the simulated columns using tropospheric $\mathrm{NO}_{2}$ columns retrieved from SCIAMACHY in April-May 2006, which are shown in the right panel of Fig. 4. The simulation underestimates the observed $\mathrm{NO}_{2}$ columns by $31 \%$ on average, with a coefficient of variation of $r^{2}=0.49$. This difference is consistent with many previous satellite-model comparisons of $\mathrm{NO}_{2}$ over East Asia for GOME (e.g. van Noije et al. (2006)), SCIAMACHY (e.g. Martin et al. (2006)), OMI and GOME-2 (e.g. Lin et al. (2010)).

We repeated this analysis using the scaled $\mathrm{NO}_{\mathrm{x}}$ emissions inventory in place of those from Zhang et al. (2007), again sampling the model during both satellite overpass times. The scaled inventory still captures much of the distribution observed by the satellites, although it includes a smaller increase in emissions, which increases the model bias only slightly $(32 \%)$ and worsens the explained variance $\left(r^{2}=0.46\right)$.

Alkane concentrations decrease as they are oxidized in the atmosphere by the $\mathrm{OH}$ radical. The logarithm of the ratio of concentrations of two different alkanes can be used as a metric for the degree of chemical processing within an air parcel (Parrish et al., 2004). Figure 5 correlates the aircraft measurements of propane and ethane, as well as the same quantity as produced by the model along the aircraft tracks. The high correlation values provide confidence that model mixing is representative of the airmasses observed at the aircraft locations. The vertical offset between the observed and simulated ratios suggests a model underestimate of propane emissions. The slight model underestimate of the slope indicates that propane is being depleted too quickly in the model relative to ethane. Most of the low values in the observations are from the lower atmospere for a single flight and may reflect a plume of clean air that is not resolved by the model.

Ozone and reactive nitrogen observations from the three aircraft platforms were also used to evaluate the emissions in the baseline simulation. Figures 6 and 7 show campaign average vertical profiles for these species as available on the three platforms. Aircraft data are plotted as yellow crosses, with black lines to represent the mean and standard deviation of the measurements at each of the model vertical levels. Each simulation was sampled at the same times and locations as the actual aircraft, and any points filtered from aircraft data as described above were excluded from the model means as well. Red lines represent campaign average profiles from the baseline simulation. Model profiles from the "Scaled 2006"

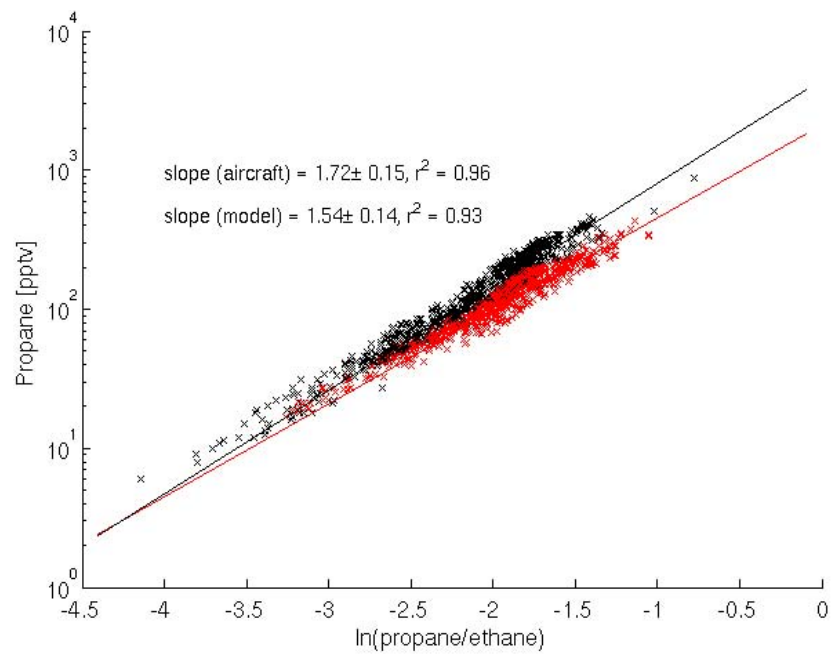

Fig. 5. Correlations of the natural logarithms of propane and ethane data taken during INTEX-B in spring 2006. Measured values and the regression line to them are shown in black; modelled values are shown in red.

simulation are excluded from these plots, because they are in all cases within $0.2 \%$ of the baseline profiles.

Ozone mixing ratio increases with altitude for all three platforms, with the standard deviation of the ozone measurements also increasing with altitude. The baseline simulation reproduces the increase with altitude observed by the aircraft. Mean biases between the baseline simulation and the C-130, DC- 8 , and Cessna ozone profiles are $-6.6 \mathrm{ppbv},+0.1 \mathrm{ppbv}$ and +4.4 ppbv, respectively (positive values indicate model overestimates). The overestimate at the Cessna location is in part due to the model averaging over the nearby city of Vancouver.

Figure 7 shows vertical profiles of peroxyacyl nitrates and nitrogen oxides from the C-130 and DC- 8 platforms, averaged over the entire INTEX-B campaign, in a manner identical to that used for the ozone profiles. The colour scheme here is the same as that described for Fig. 6.

The peroxyacyl nitrate mean profiles from the DC-8 and the C-130 exhibit a characteristic increase with altitude, reflecting the temperature dependence of PAN dissociation. $\mathrm{NO}_{\mathrm{x}}$ has a C-shaped profile, reflecting the increased lifetime of $\mathrm{NO}_{\mathrm{x}}$ at high altitudes and the combination of lower and upper tropospheric sources, including PAN dissociation near the surface in the remote troposphere. The reactive nitrogen profiles display significant agreement between the baseline simulation and the in situ measurements for $\mathrm{NO}_{\mathrm{x}}$ (mean bias of $3.0 \mathrm{pptv}$ for the C-130 and $-28 \mathrm{pptv}$ for the DC- 8 ) and peroxyacyl nitrates $(-9.4 \mathrm{pptv}$ for the C-130 and $-58 \mathrm{pptv}$ for the DC-8). The agreement for $\mathrm{NO}_{\mathrm{x}}$ may be fortuitous as the $\mathrm{NO}$ and $\mathrm{NO}_{2}$ observations are not in photochemical steady state (Zhang et al., 2008). Simulated $\mathrm{HNO}_{3}$ is biased high relative to the aircraft measurements by a factor of $2-3$, 

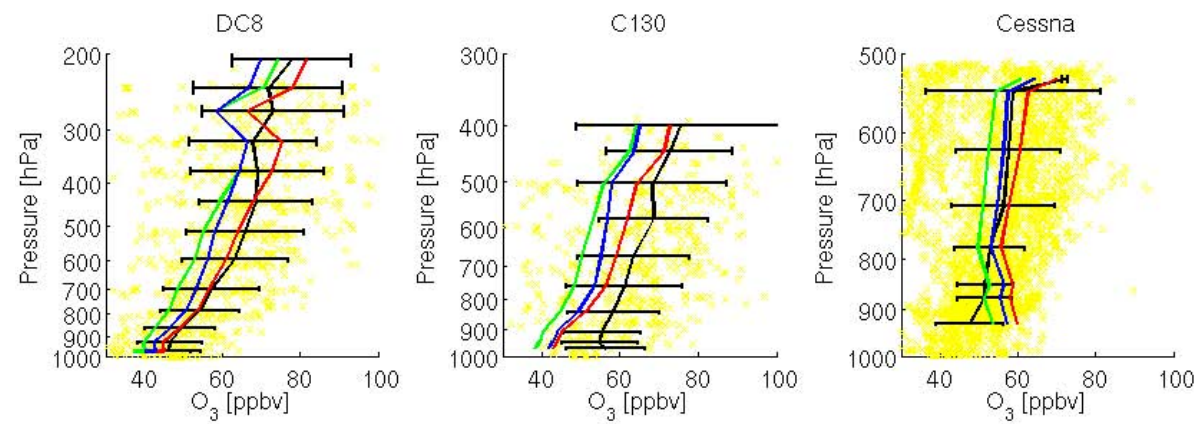

Fig. 6. Campaign average vertical profiles of ozone for C-130, DC-8, and Cessna aircraft. Aircraft data are plotted as yellow crosses, with black lines to represent the mean and standard deviation of the measurements at each of the model vertical levels. Red lines represent campaign average profiles from the baseline simulation; green, from the "no Asia" simulation; and, blue, from the "no lightning" simulation. Simulations are sampled along the aircraft flight tracks.
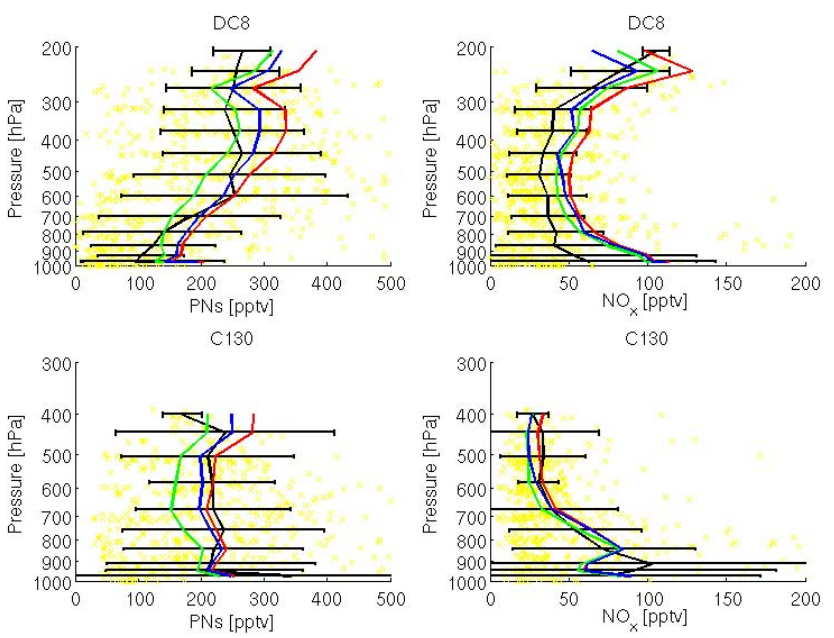

Fig. 7. Campaign average vertical profiles of peroxyacyl nitrates and nitrogen oxides for the $\mathrm{C}-130$ and $\mathrm{DC}-8$ aircraft. $\mathrm{NO}_{\mathrm{x}}$ from both platforms was obtained from the chemiluminescence instruments. PANs on the C-130 were measured with PAN-CIGAR, and PANs on the DC- 8 by the TD-LIF instrument. Aircraft data are plotted as yellow crosses, with black lines to represent the mean and standard deviation of the measurements at each of the model vertical levels. Red lines represent campaign average profiles from the baseline simulation; green, from the "no Asia" simulation; and, blue, from the "no lightning" simulation. Simulations are sampled along the aircraft flight tracks.

reflecting a model underestimate in wet deposition (Fairlie et al., 2009).

The two IONS ozonesonde sites provide yet another means for evaluating the simulation. Figure 8 shows the mean ozone profiles, with sonde data plotted as yellow crosses and the mean and standard deviation of the measurements shown with black lines. Modelled and measured ozone mixing ratios both increase with altitude. The baseline simulation reproduces the ozone profiles at the two Canadian sites with mean biases of $-3.0 \mathrm{ppbv}$ at Kelowna and $-7.7 \mathrm{ppbv}$ at
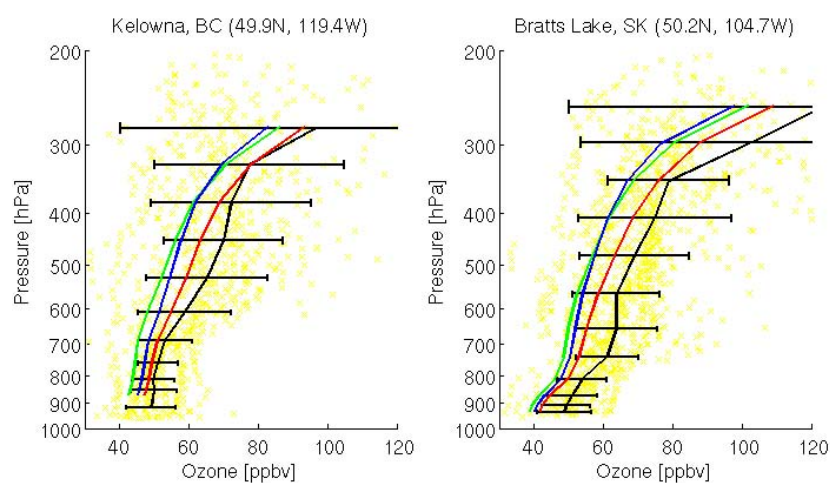

Fig. 8. Mean vertical profiles of ozone in the troposphere from ozonesondes at Kelowna, BC (left) and Bratt's Lake, SK (right). Yellow crosses represent sonde data. Black lines represent the mean and standard deviation of the measurements. Red lines represent campaign average profiles from the baseline simulation; green, from the "no Asia" simulation; and, blue, from the "no lightning" simulation. Measurements are filtered for stratospheric influence (ozone $>120 \mathrm{ppbv}$ ).

Bratt's Lake. Hudman et al. (2004) found a similar underestimate in simulated GEOS-Chem ozone versus observations over California in spring due to insufficient ozone of stratospheric origin.

\subsection{Sources of ozone over the North Pacific Ocean}

We now use sensitivity studies to evaluate the importance of various emission sources and chemical mechanisms for producing observed ozone distributions in the Pacific. The top right panel of Fig. 9 shows cloud-filtered tropospheric ozone columns retrieved from OMI averaged over April-May 2006 (Liu et al., 2010). The data are filtered to exclude retrievals with average fitting residuals greater than 1.5 relative to the measurement error, cloud fractions greater than 0.3 , retrievals that use a total weighted area in the grid cell of less than 0.25 , and retrievals with less than 0.5 degrees 

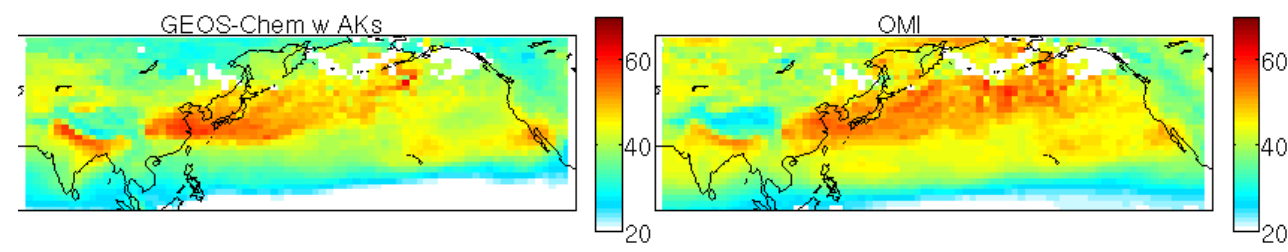

[DU]

[DU]
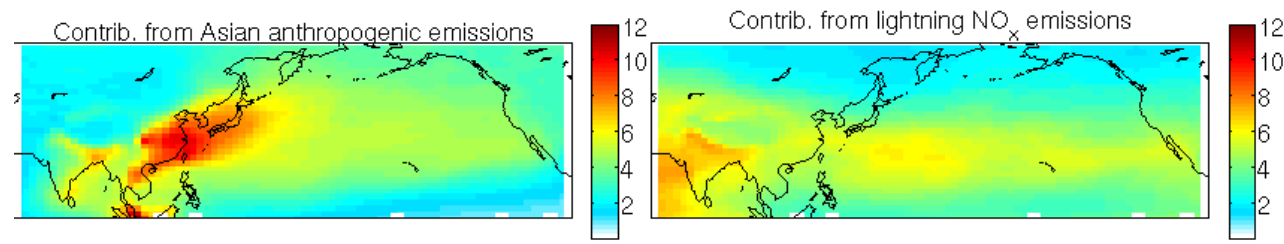

[DU]

[DU]

Fig. 9. Comparison between simulated and observed tropospheric ozone columns. The top row contains tropospheric ozone columns from the baseline simulation convolved with the OMI averaging kernels, and those retrieved from OMI by Liu et al. (2010). The bottom row shows simulated contributions to the tropospheric $\mathrm{O}_{3}$ columns due to lightning $\mathrm{NO}_{\mathrm{x}}$ emissions and due to Asian anthropogenic emissions as determined by difference with simulations that exclude either source.

of freedom for signal in the troposphere. Both the satellite and simulation tropospheric columns are calculated using the same tropopause height. A broad maximum extends across the mid-latitude Pacific, exhibiting a decrease from west to east that is indicative of Asian outflow and net chemical loss. The top left panel of Fig. 9 shows simulated tropospheric ozone columns from the baseline simulation, sampled at the OMI overpass time, convolved with the OMI averaging kernels, and averaged over the same two-month period. The simulated columns also show the broad Asian outflow features, although the simulation tends to under-predict the satellite tropospheric columns by $3.7 \mathrm{DU}(7.7 \%)$ on average in the Pacific.

The lower two panels of Fig. 9 show the sensitivity of tropospheric ozone columns to the lightning $\mathrm{NO}_{\mathrm{x}}$ and Asian anthropogenic emissions sources as determined by difference between the baseline simulation and a sensitivity simulation excluding either source. This approach underestimates the true source contribution since ozone production is more sensitive to $\mathrm{NO}_{\mathrm{x}}$ at low $\mathrm{NO}_{\mathrm{x}}$ concentrations (Liu et al., 1987). Following Sauvage et al. (2007), values will be preceded by ">" to emphasize this nonlinearity. The contribution due to the lightning source is greatest in the tropics $(>14 \mathrm{DU})$, but remains substantial at mid-latitudes $(>3.2 \mathrm{DU}$ on average over the Pacific between $30^{\circ}$ and $60^{\circ} \mathrm{N}$ ). The contribution due to Asian anthropogenic emissions shows a broad maximum (peak value $>11 \mathrm{DU}$ ) that extends over Japan and into the western Pacific. The mean contribution from Asian emissions in the Pacific between $30^{\circ}$ and $60^{\circ} \mathrm{N}$ is $>4.6 \mathrm{DU}$. The mean Asian contribution over western Canada ( $>3.3 \mathrm{DU})$ is comparable to that over the western coastal US ( $>4.2 \mathrm{DU}$ ). A separate tagged- $\mathrm{O}_{\mathrm{x}}$ simulation shows a reasonable contribu-
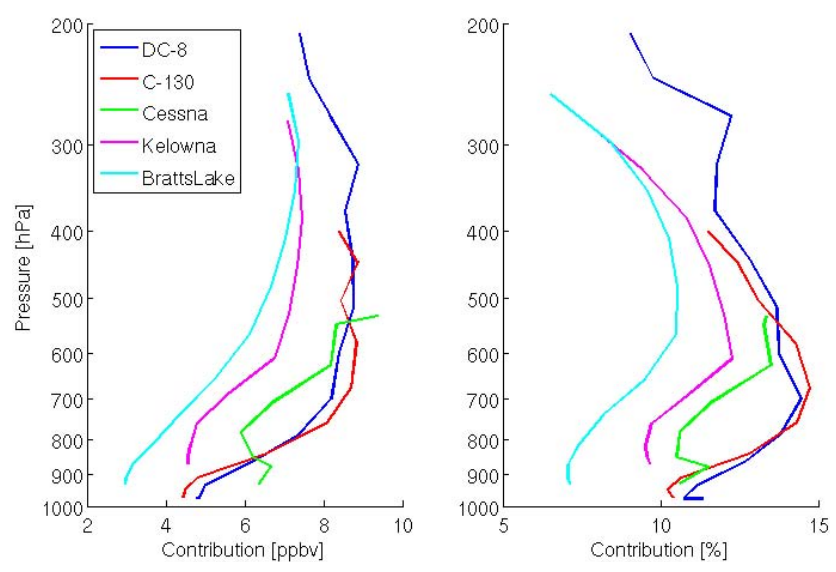

Fig. 10. Vertical profiles of the mean difference between baseline and "no Asia" simulations at the locations of the three aircraft and two ozonesonde observations.

tion from the stratosphere to the tropospheric columns over the North Pacific Ocean in the spring, 20 DU on average. By comparison, Lelieveld and Dentener (2000) find an annual mean contribution of the stratosphere to the tropospheric column over Canada of $42 \%$.

Figures 6, 7, and 8 offer further insight into the influence of the lightning and Asian anthropogenic emissions sources. Blue and green lines in these figures show simulated profiles excluding these two sources. The difference between these profiles and the baseline represents the simulated contribution to the profiles from this source. This is shown more clearly in Fig. 10, which shows the difference between the baseline and "no Asia" simulations at the locations of all 


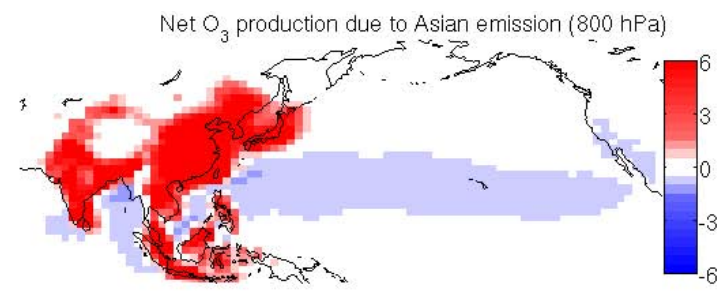

ppbviday

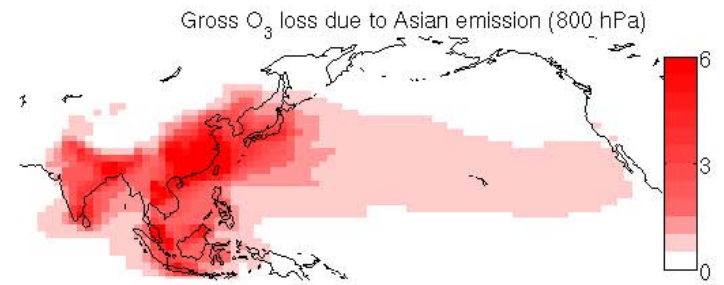

ppbv/day

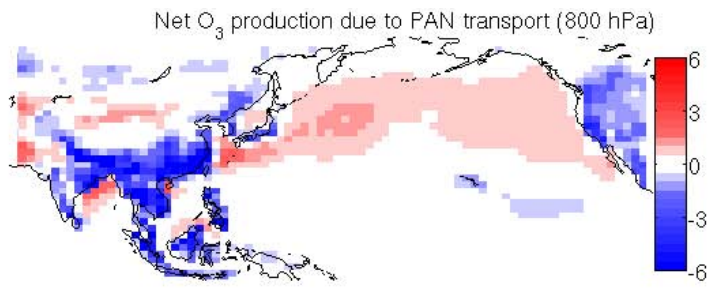

ppbv/day

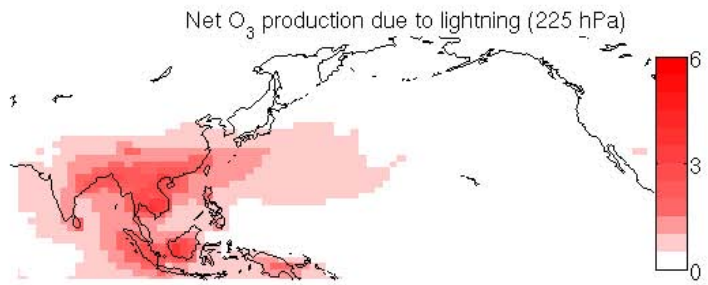

ppbv/day

Fig. 11. Model studies of $\mathrm{O}_{3}$ production in spring 2006. Net $\mathrm{O}_{3}$ production at $2 \mathrm{~km}$ due to Asian anthropogenic emissions is shown on the top left, while net $\mathrm{O}_{3}$ production due to PAN transport at $2 \mathrm{~km}$ is displayed in the top right. The bottom left panel shows the gross loss of $\mathrm{O}_{3}$ due to Asian anthropogenic emissions at $2 \mathrm{~km}$. The bottom right panel displays net $\mathrm{O}_{3}$ production due to the lightning $\mathrm{NO}_{\mathrm{x}}$ source at $11 \mathrm{~km}$.

three aircraft and the two ozonesonde stations. For all locations, the contribution due to Asian anthropogenic emissions is greatest in the lower free troposphere between 600 and $700 \mathrm{hPa}$, reaching $>8.9 \mathrm{ppbv}$, whereas the contribution due to lightning (Fig. 6) is greatest in the upper troposphere, reaching $>12 \mathrm{ppbv}$ in the DC-8 mean profile. The contribution from Asian anthropogenic emissions to the ozone profiles above Whistler is $6-8 \mathrm{ppbv}$ on average. The reactive nitrogen profiles (Fig. 7) contain a substantial contribution from Asian emissions in PANs, accounting for up to a third of the PAN present. As we will show in the section that follows, PANs play an important role in ozone production over the remote North Pacific.

\section{Transpacific transport pathways}

\subsection{Role of PAN Transport}

Ozone in the remote troposphere is affected by transport from regions with net photochemical production including downward flux from the stratosphere, and in situ production from transported precursors, both natural and anthropogenic. The INTEX-B data set provides a useful opportunity to examine the sources of ozone above the eastern North Pacific Ocean, and to evaluate its dependence on in situ net production of ozone compared to direct transport from a polluted region.

The top left panel of Fig. 11 shows the simulated contribution to net $\mathrm{O}_{3}$ production due to Asian anthropogenic emissions, again obtained by difference with a simulation that excludes Asian anthropogenic emissions. Maximum net pro- duction due to Asian pollution occurs above and downwind of regions with high $\mathrm{NO}_{\mathrm{x}}$ emissions, while over the central and eastern Pacific Ocean net production is nearly zero, even slightly negative (i.e. $\mathrm{O}_{3}$ destruction) at more southern latitudes. In an average sense, net ozone production due to Asian sources occurs primarily over Asia and then is transported across the Pacific. We find a similar pattern throughout the lower troposphere.

The top right panel of Fig. 11 displays net $\mathrm{O}_{3}$ production due to PAN transport, obtained by difference between the baseline and "no PAN" simulations, following Moxim et al. (1996). This contribution and that due to Asian emissions are not mutually exclusive, since a fraction of the PAN transported does originate from Asian anthropogenic emissions. Also, the contribution due to PAN transport calculated here is a low-end estimate because our approach assumes PAN formation in the source region is decoupled from ozone production. The simulation without PAN chemistry will overestimate direct ozone export from the source region because the lifetime of $\mathrm{NO}_{\mathrm{x}}$ there is extended.

In the top right panel of Fig. 11, a net loss of $\mathrm{O}_{3}$ is apparent over the Asian source regions, reflecting PANs removing $\mathrm{NO}_{\mathrm{x}}$ from near the surface and transporting it elsewhere. Consequent to this redistribution, an enhancement to net production occurs both immediately downwind, over the Yellow Sea and east of Japan, and also above the eastern Pacific. The latter region was previously observed to be a location of subsidence of transported PANs from the upper troposphere (Heald et al., 2003; Hudman et al., 2004; Zhang et al., 2008). Ozone production due to PAN transport is disproportionate 


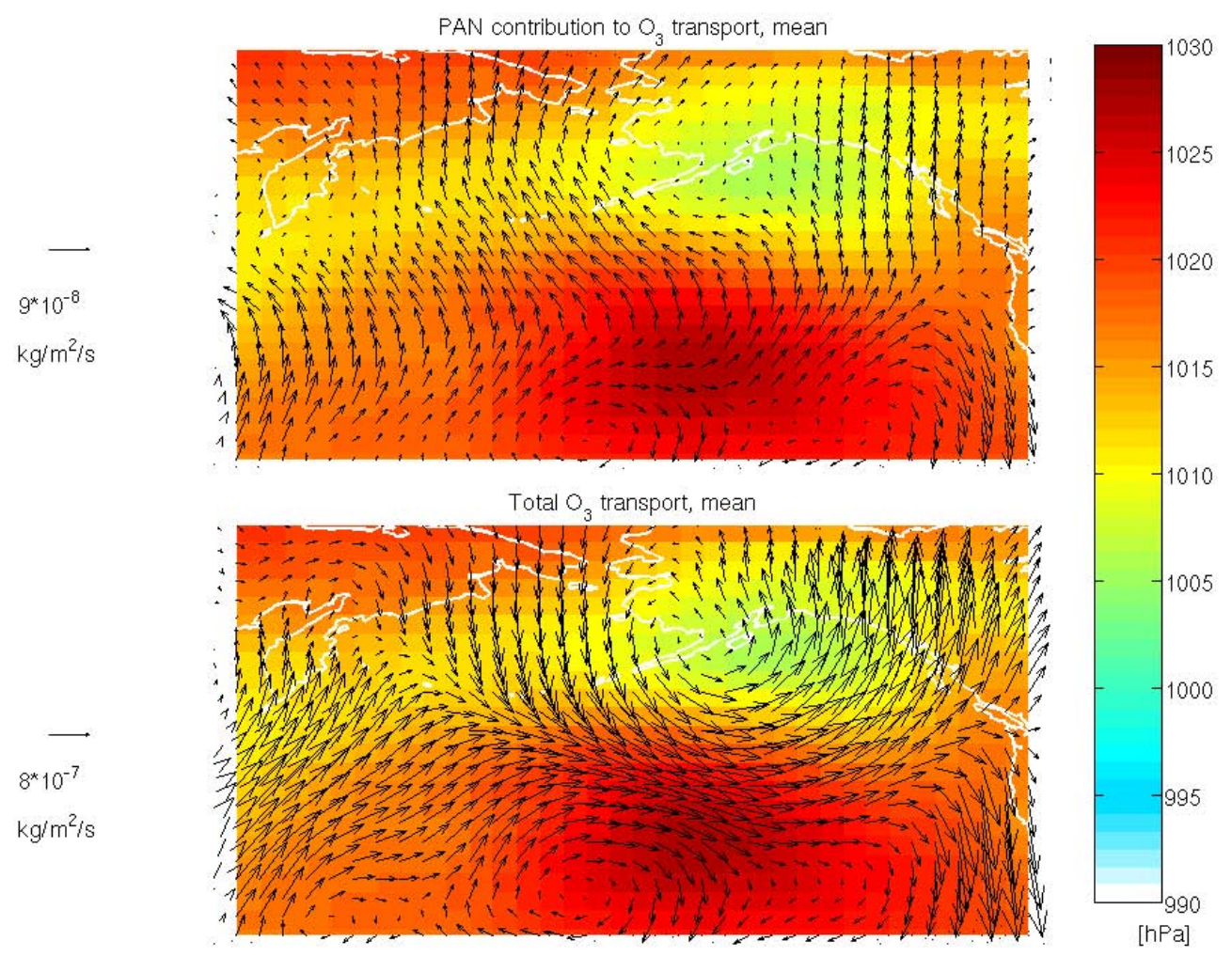

Fig. 12. Simulated ozone fluxes at $2 \mathrm{~km}$ averaged over the campaign. The two panels overlay mean surface pressure maps over the campaign with average fluxes of total $\mathrm{O}_{3}$ and that are due to transport of PANs.

to loss because PAN removes $\mathrm{NO}_{\mathrm{x}}$ from a location with low ozone production efficiency and injects it into a remote region where ozone production efficiency is higher, resulting in a global increase of $2 \%$ in net $\mathrm{O}_{3}$ production.

The net ozone production due to Asian emissions can still be near zero above the eastern Pacific Ocean if the gross production due to PAN transport is balanced by a gross loss that is also due to Asian emissions. Gross loss of $\mathrm{O}_{3}$ due to Asian anthropogenic emissions is shown in the bottom left panel of Fig. 11. The spatial distribution of the loss follows closely the distribution of $\mathrm{O}_{3}$ itself from this source, as we expect for a first-order loss process. Examining the effect of PANs on the ozone budget, we find that PAN transport is required for gross production to exceed gross loss as far as the eastern Pacific.

Lightning is a natural source of ozone precursors, and can thus contribute to its production in the remote troposphere. The bottom right panel of Fig. 11 shows the ozone produced due to lightning at $225 \mathrm{hPa}$, obtained by difference with the "no lightning" simulation. A maximum over Indonesia and Thailand is apparent, with some transport immediately downwind. Upper tropospheric ozone production due to lightning emissions at northern mid-latitudes is 1$3 \mathrm{ppbv/day,} \mathrm{comparable} \mathrm{to} \mathrm{the} \mathrm{effect} \mathrm{of} \mathrm{PAN} \mathrm{in} \mathrm{the} \mathrm{lower}$ troposphere.

\subsection{Case study: 4-5 May 2006}

Transit time analysis has shown that trans-Pacific transport of Asian outflow has both midltatitude and subtropical modes during spring (Holzer and Hall, 2007). Furthermore, Zhang et al. (2008) identified two branches of the midlatitude Asian transport plume that were both sampled by the aircraft during the INTEX-B campaign. The southern branch subsides into the lower troposphere off the west coast of California, while the northern branch remains in the mid-troposphere and circles off to the northeast. Zhang et al. (2008) focus on the southern branch, which has a greater impact on the United States. Here we explore how both branches affect Canadian air quality. We examine the May 4-5 transport event using the aircraft observations and sensitivity simulations to identify transport pathways whereby this transported pollution could reach western Canada.

Figure 12 displays the mean surface pressure during the INTEX-B campaign. It is characterized by a strong low pressure system over Alaska and a strong high directly south, the combination of which allows for rapid advection across the ocean (Liang et al., 2005). Overlaid on these maps is the total ozone flux at $2 \mathrm{~km}$ altitude (second panel) and the contribution to this flux due to PAN transport (top panel). The total flux at this altitude curls around the high, then back to the north, following the Aleutian low. Near the high, PAN leads 


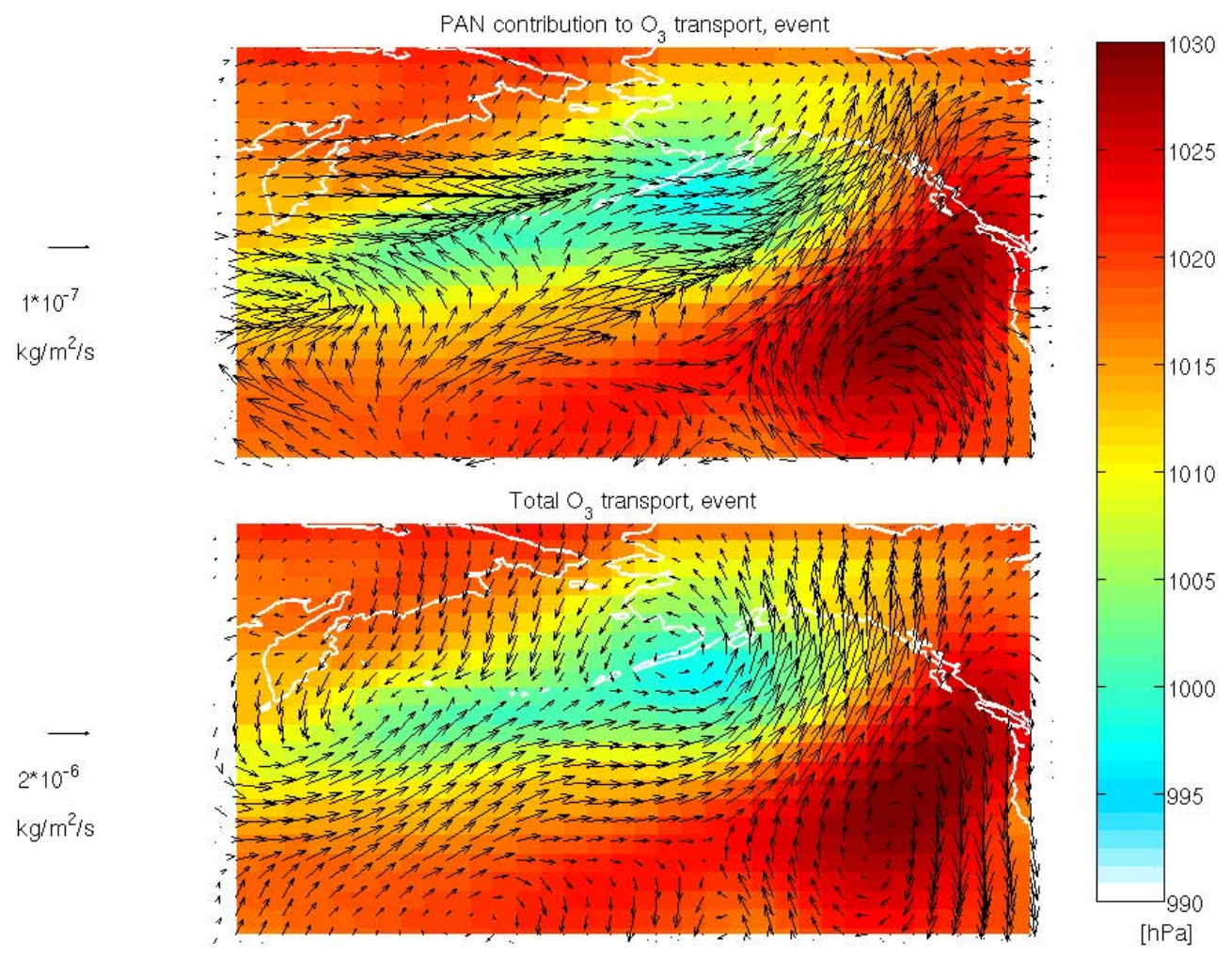

Fig. 13. Simulated ozone fluxes at $2 \mathrm{~km}$ averaged during the 4 May 2006 event. The two panels show the surface pressure and ozone fluxes on 4 May 2006.

to the production of $>4.7 \%$ of the total ozone flux, further evincing that subsidence around this high brings PANs down from the upper troposphere, contributing to the ozone signal in this region.

Aircraft observations, meteorology, and simulated fields during the INTEX-B campaign reveal distinct transport events where ozone was advected into the North American continent. Figure 13 focuses on the ozone flux and surface pressures on May 4. The pattern in surface pressures is similar to the campaign means shown Figure 12, although here the Alaskan low is broader and even more pronounced, and the high over the eastern North Pacific Ocean extends up the western North American coast. This shifts the fast transport conduit between the two systems to be directed northeastward into British Columbia. The contribution from PANs to the total ozone flux is quite high $(>12.3 \%)$ in the eastern Pacific along this conduit.

Further corroboration of the May 4 event is provided by the DC- 8 observations. Figure 14 shows the flight track out of Anchorage that day, underlaid by the contribution to ozone concentrations due to PAN transport in the top left panel and the contribution from Asian emissions in the top right. The plots in the bottom panel of Fig. 14 focus on measurements during the westbound leg of the flight with the blue, magenta, and cyan markers indicating the aircraft's location. The simulation reproduces the general shape of the obser- vations but lacks the resolution to capture the brief peaks in concentration encountered by the aircraft. When the plane exited the boundary layer (magenta marker), it encountered a dry airmass with ozone (115 ppbv), CO (204 ppbv), and PAN (1125 pptv) substantially elevated above background levels. As the flight continued westward, these concentrations returned to close to background values. The simulated contribution to ozone due to Asian emissions near this altitude is $>10 \mathrm{ppbv}$, while the contribution from PAN transport is near zero.

The following day, the C-130 flew west from Seattle over the Pacific. It also observed a dry airmass at $700 \mathrm{hPa}$ with elevated ozone (114 ppbv), CO (188 ppbv), and PAN (512 ppb), similar to what the DC- 8 observed one day prior. Backtrajectories from the C-130 flight track intersect with the track of the DC- 8 on the previous day. Figure 15 shows the flight track and data series from the C-130 aircraft measurements. The C-130 appears to have flown through the same plume during both its descent (magenta marker) and ascent (cyan marker). Finally, the Cessna flight on May 5 encountered an airmass with elevated ozone between $3 \mathrm{~km}$ and $4 \mathrm{~km}$ coincident with a sulphate aerosol plume (Leaitch et al., 2009).

While the simulated contribution to the ozone concentration in the $\mathrm{C}-130$ flight due to Asian emissions remained as high as for the DC-8, the contribution due to PANs increased to 3 ppbv. If the two aircraft are sampling the same airmass, 

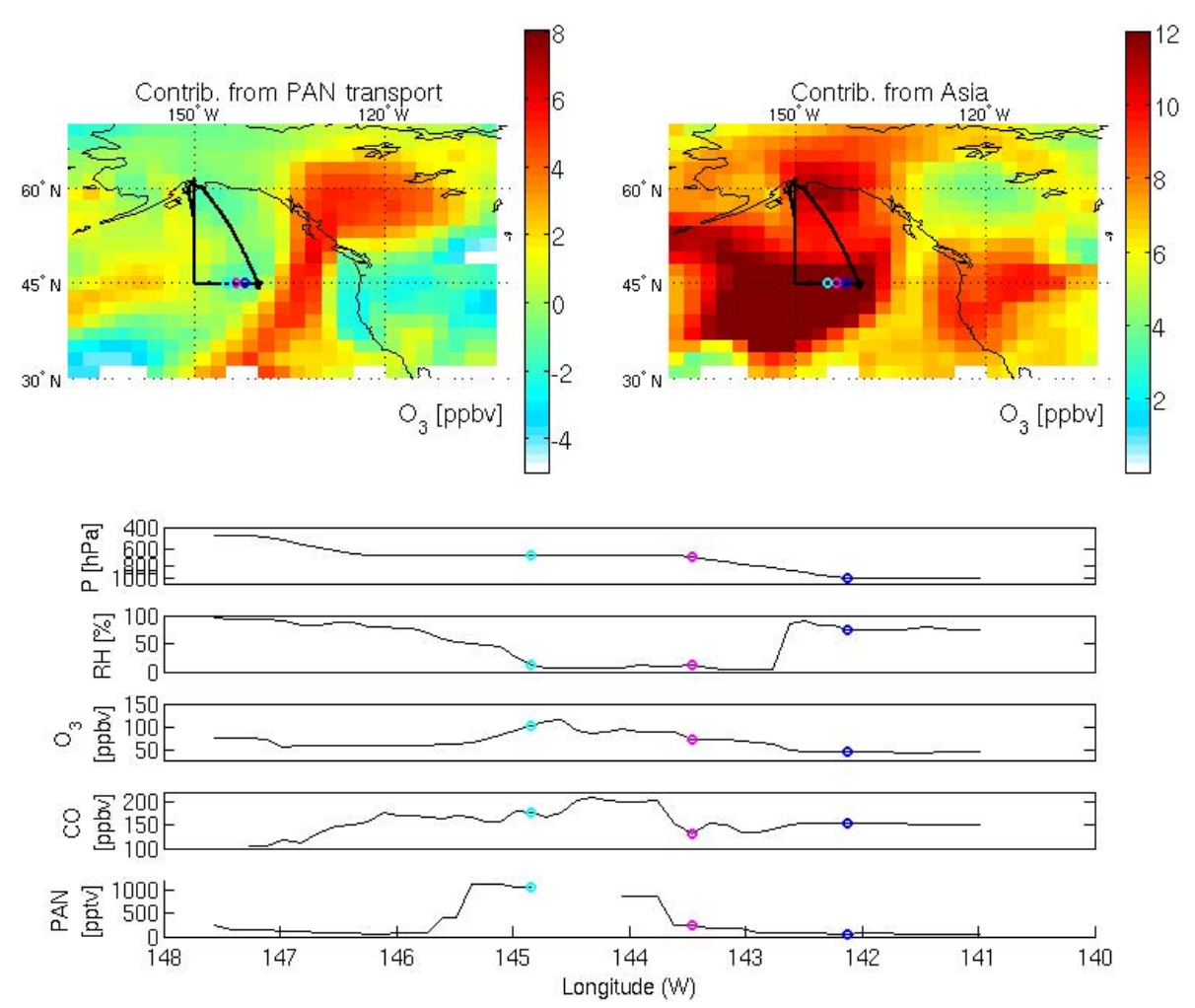

Fig. 14. Detail of the DC-8 measurements during the May 4, 2006 transport event. The top left panel shows the flight track of the DC-8 on May 4, 2006 overlaid on the simulated contribution to ozone concentrations due to transport of PANs at $4 \mathrm{~km}$. The top right panel displays the flight track atop the contribution from Asian emissions. The bottom plots show aircraft measurements during the westbound leg, where the aircraft encounters a plume of elevated $\mathrm{O}_{3}, \mathrm{CO}$, and PANs at about $700 \mathrm{hPa}$. Blue, magenta, and cyan circles mark the location of the aircraft on the maps during the data series.

as the model suggests, some of the elevated PAN from May 4 must have dissociated, triggering ozone production. This is consistent with the southern branch of transport identified in Zhang et al. (2008). However, the peak ozone mixing ratio observed on the $\mathrm{C}-130$ was within $2 \%$ of that observed by the DC-8, likely reflecting dilution and chemical destruction.

The northern branch of the transported plume is also represented in the simulation. Figure 16 shows the contribution to the ozone concentration at $2 \mathrm{~km}$ due to PAN transport over 5 days, concluding on 5 May 2006. The maximum contribution is over the eastern North Pacific Ocean, and on 2 through 4 May, the northeastward progress of an airmass affected by PAN transport is observed. This follows from the flux fields shown in Fig. 13, which also show strong northeastward advection during this event. The affected airmass enters Canada on 3May, having a contribution at this altitude of up to $7 \mathrm{ppbv}$ from PAN transport. The sensitivity simulation suggests other similar events during spring 2006, although the INTEX-B flights were not situated to intercept them.

\section{Conclusions}

The INTEX-B campaign in spring 2006 provided observations of ozone and reactive nitrogen over the North Pacific Ocean and western North America. We interpreted these observations using the GEOS-Chem global chemical transport model to study the sources and transport mechanisms that produce ozone in the remote Pacific and to identify pathways for transported pollution entering North America, with particular attention to Canada.

We studied ozone measurements from a Canadian Cessna207 in the broader context of the INTEX-B campaign. The Cessna-207 flew 33 flights out of Pemberton, BC, typically performing a vertical profile near Whistler Peak, BC. Two intercomparison flights between the C-130 and Cessna platforms were performed. Mean vertical ozone profiles for these two flights agree to within 5 ppbv, with the C-130 being higher than the Cessna.

We developed a method to apply changes in $\mathrm{NO}_{2}$ columns to infer changes in $\mathrm{NO}_{\mathrm{x}}$ emissions. The local scale factor is inferred from a GEOS-Chem simulation. We constructed a timely $\mathrm{NO}_{\mathrm{x}}$ emissions inventory over East Asia using satellite observations of tropospheric $\mathrm{NO}_{2}$ columns 

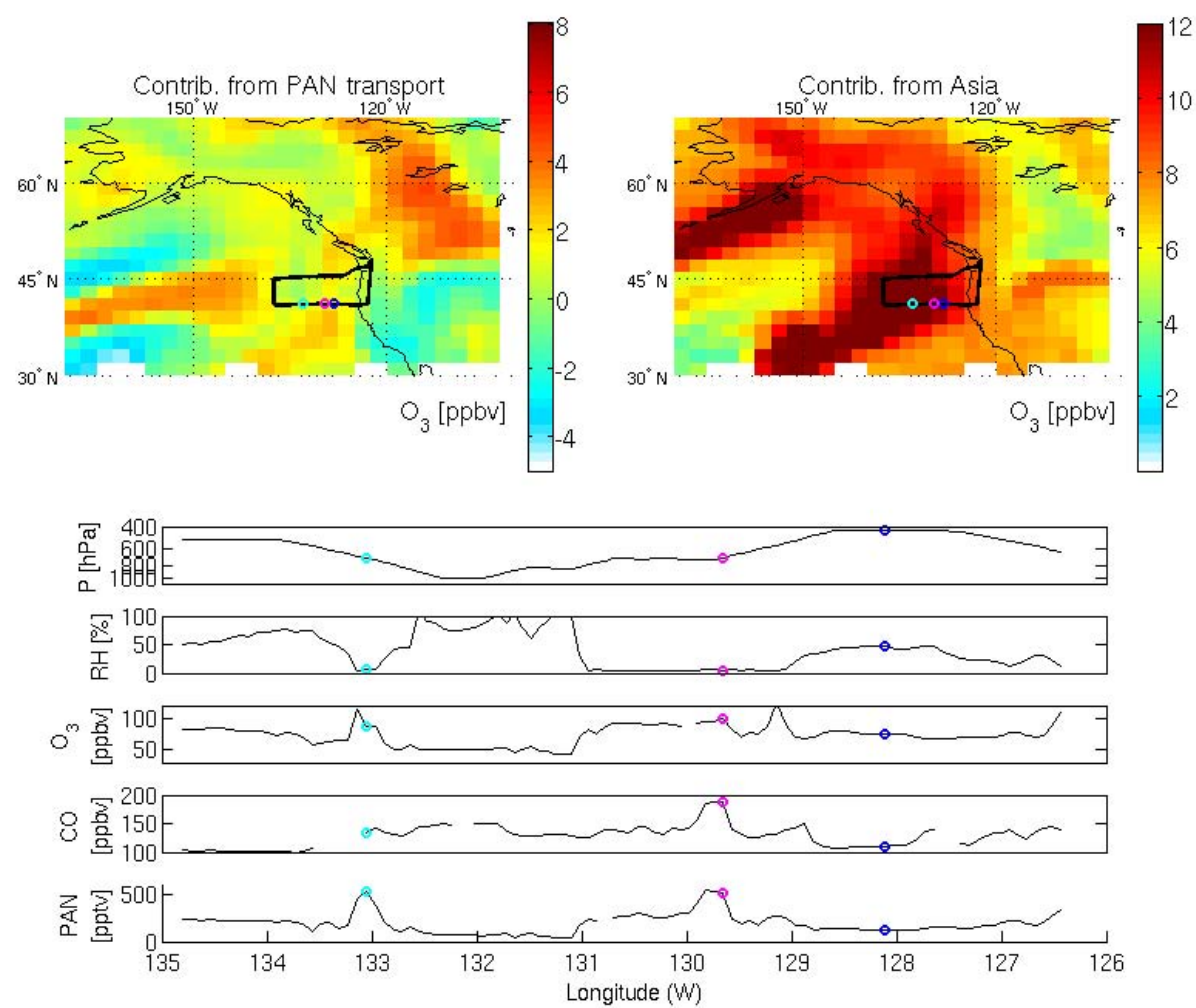

Fig. 15. Detail of the C-130 during the May 5, 2006 transport event. The left panel shows the flight track of the C-130 on May 5, 2006 overlaid on the simulated contribution to ozone concentrations due to transport of PANs at $4 \mathrm{~km}$. The top right panel displays the flight track atop the contribution from Asian emissions. The bottom plots show aircraft measurements during the westbound leg where the aircraft encounters a plume of elevated $\mathrm{O}_{3}, \mathrm{CO}$, and PANs at about $700 \mathrm{hPa}$. Blue, magenta, and cyan circles mark the location of the aircraft on the maps during the data series.
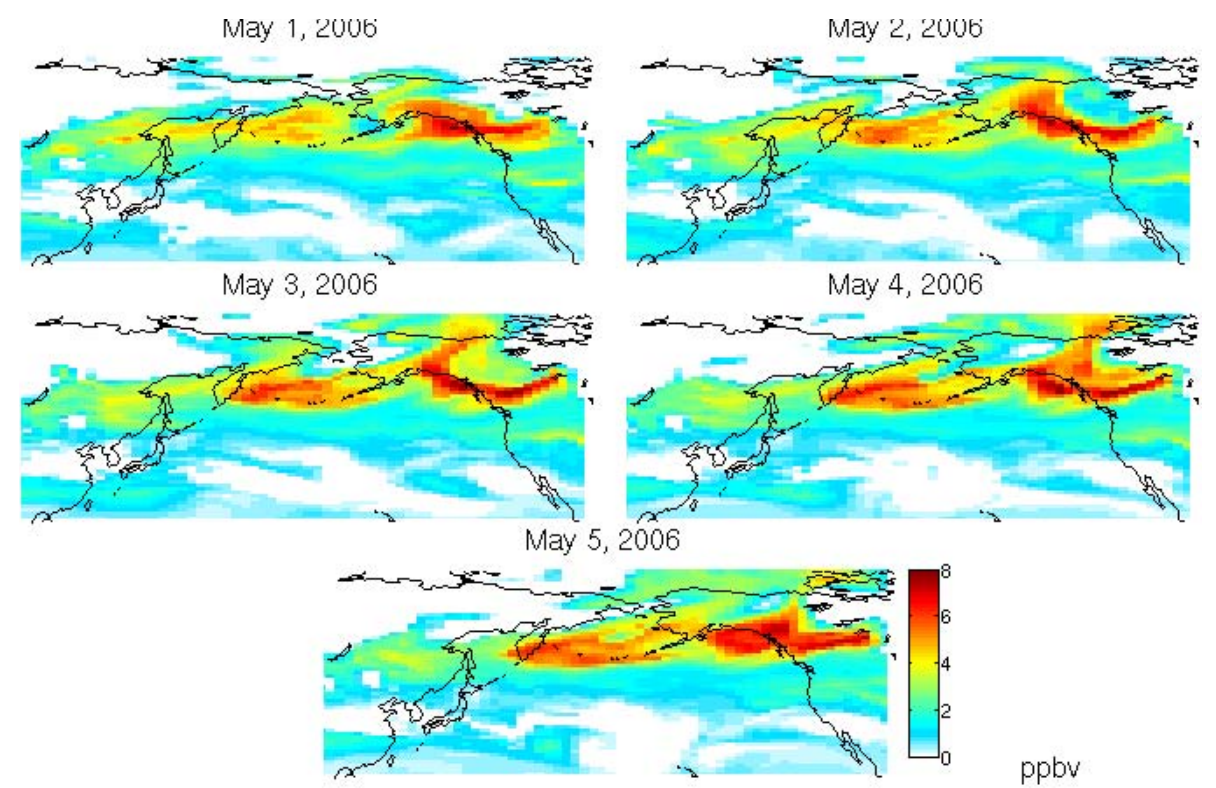

ppbv

Fig. 16. Ozone due to transport of PANs from 1-5 May 2006. Panels show the contribution from PAN transport at $2 \mathrm{~km}$, obtained from difference between the baseline and "no PAN" simulations. 
from the SCIAMACHY satellite instrument. This scaling increased $\mathrm{NO}_{\mathrm{x}}$ emissions in the region by $2.5 \mathrm{TgNyr}^{-1}$ since 2003, yielding results comparable to a recent bottom-up inventory (Zhang et al., 2009b). Satellite observations provide both a global record that extends for several years and also observations that are timely, allowing this method to be used to scale emission inventories in regions where an up-to-date bottom-up inventory is unavailable.

Our baseline simulation reproduces profiles of ozone and reactive nitrogen observed by the aircraft in the Pacific and by ozonesondes over North America. Ozone profiles are reproduced to within $7 \mathrm{ppbv}$, while $\mathrm{PAN}$ and $\mathrm{NO}_{\mathrm{x}}$ profiles match observed profiles within $30 \%$, similar to those reported in (Zhang et al., 2008). Sensitivity simulations were conducted to examine the roles of emissions and chemical processes to the ozone background. Asian anthropogenic emissions contributed at least 8.9 ppbv to mean ozone profiles at the aircraft locations, while lightning contributed at least $12 \mathrm{ppbv}$ in the upper troposphere at these locations. The baseline simulation also captures the broad Asian outflow feature apparent in tropospheric ozone columns in the Pacific observed by OMI, with the simulation biased low by 3.7 DU in the Pacific. Asian anthropogenic emissions contribute a maximum of $11 \mathrm{DU}$, with a mean contribution to the columns over the Pacific of 4.6 DU. The mean lightning contribution to Pacific ozone columns is 3.2 DU. The comparable contributions from lightning and Asian sources imply that a thorough understanding of the uncertain lightning source of $\mathrm{NO}_{\mathrm{x}}$, as well as other anthropogenic and natural sources, will be necessary to fully quantify the implications of Asian anthropogenic emissions.

A sensitivity study where PANs were treated as nonreactive was used to examine the role of PAN transport of reactive nitrogen to ozone production over the Pacific. PANs remove $\mathrm{NO}_{\mathrm{x}}$ from polluted source regions and redistribute it to remote regions where ozone production efficiency is high, resulting in a $2 \%$ global increase in net $\mathrm{O}_{\mathrm{x}}$ production. The simulated contribution of PAN transport to net $\mathrm{O}_{\mathrm{x}}$ production extends across the mid-latitude Pacific, with a mean contribution of 1.6 ppbvday $^{-1}$. Removal of Asian anthropogenic emissions results in a decrease in PANs in the eastern Pacific of $31 \%$ and a loss of $32 \%$ of the $\mathrm{O}_{\mathrm{x}}$ production due to PAN transport.

Elevated ozone concentrations in the western Pacific can be explained by a combination of direct outflow of ozone from the pollution regions of Asia and near-field production from ozone precursors, and production in the eastern Pacific. This production is caused by transport of PANs of Asian origin in the upper troposphere subsiding in the east Pacific.

A transport pathway was identified whereby ozone entered continental North America during the spring of 2006. The main subsidence region was in a persistent high pressure system in the eastern mid-latitude Pacific, where ozone production due to subsidence of transported PANs was inferred from sensitivity simulations. This ozone is then ad- vected northeastward into the northwestern United States and Canada. Several events observed by the aircraft platforms during INTEX-B contained elevated levels of ozone ( $>95 \mathrm{ppbv}), \mathrm{CO}(>150 \mathrm{ppbv})$, and PANs ( $>500 \mathrm{pptv})$. These events were observed at $2 \mathrm{~km}$ elevation, at times when the dominant flow was directed northeastward, circling the Aleutian low.

Acknowledgements. This work was supported by the Special Research Opportunity Program of the Natural Science and Engineering Research Council (NSERC) of Canada. Thomas Walker was supported by an NSERC Canadian Graduate Scholarship. The DC8 and C-130 measurements were supported by NASA and NSF.

Rob Buchanan provided professional and tireless piloting of the Cessna during the study. Tragically, Rob lost his life in the crash of the Cessna following the conclusion of the study. Mohammed Wasey, Armand Gaudenzi, Dave Halpin and John Deary provided technical and logistical support. Special thanks to Juniper Buller, Anton Horvath, the Whistler Ski Patrol and Whistler Blackcomb for their support.

Edited by: H. Singh

\section{References}

Allen, D., Pickering, K., and Fox-Rabinovitz, M.: Evaluation of pollutant outflow and $\mathrm{CO}$ sources during TRACE-P using modelcalculated, aircraft-based, and Measurements of Pollution in the Troposphere (MOPITT)-derived CO concentrations, J. Geophys. Res., 109 (D15S03), doi:10.1029/2003JD004250, 2004.

Bailey, R., Barrie, L. A., Halsall, C. J., Fellin, P., and Muir, D. C. G.: Atmospheric organochlorine pesticides in the western Canadian Arctic: Evidence of transpacific transport, J. Geophys. Res., 105 (D9), 11 805-11 812, 2000.

Berntsen, T., Isaksen, I. S. A., Wang, W.-C., and Liang, X.-Z.: Impacts of increased anthropogenic emissions in Asia on tropospheric ozone and climate: A global 3-D model study, Tellus, 48B, 13-32, 1996.

Berntsen, T. K., Karlsdóttir, S., and Jaffe, D. A.: Influence of Asian emissions on the composition of air reaching the North Western United States, Geophys. Res. Lett., 26, 2171-2174, 1999.

Bey, I., Jacob, D. J., Logan, J. A., and Yantosca, R. M.: Asian chemical outflow to the Pacific: origins, pathways and budgets, J. Geophys. Res., 106, 23 097-23 114, 2001 a.

Bey, I., Jacob, D. J., Yantosca, R. M., Logan, J. A., Field, B. D., Fiore, A. M., Li, Q., Liu, H. Y., Mickley, L. J., and Schultz, M. G.: Global modeling of tropospheric chemistry with assimilated meteorology: Model description and evaluation, J. Geophys. Res., 106, 23 073-23 096, $2001 \mathrm{~b}$.

Bovensmann, H., Burrows, J. P., Buchwitz, M., Frerick, J., Rozanov, V. V., Chance, K. V., and Goede, A. P. H.: SCIAMACHY: Mission objectives and measurement modes, J. Atmos. Sci., 56, 127-150, 1999.

Browell, E. V., Fenn, M. A., Butler, C. F., Grant, W. B., Brackett, V. G., Hair, J. W., Avery, M. A., Newell, R. E., Hu, Y., Fuelberg, H. E., Jacob, D. J., Anderson, B. E., Atlas, E. L., Blake, D. R., Brune, W. H., Dibb, J. E., Fried, A., Heikes, B. G., Sasche, G. W., Sandholm, S. T., Singh, H. B., Talbot, R. W., Vay, S. A., Weber, 
R. J., and Bartlett, K. B.: Large-scale ozone and aerosol distributions, air mass characteristics, and ozone fluxes over the western Pacific Ocean in late winter/early spring, J. Geophys. Res., 108, doi:10.1029/2002JD003290, 2003.

Chen, G., Kleb, M. M., Brune, W. H., et al.: An Overview of INTEX-B/MILAGRO/IMPEX Instrument and Measurement Intercomparison, Eos Trans. AGU, 88(52), Fall Meet. Suppl., Abstract A33A-0817, 2007.

Christian, H. J., Blakeslee, R. J., Boccippio, D. J., Boeck, W. L., Buechler, D. E., Driscoll, K. T., Goodman, S. J., Hall, J. M., Koshak, W. J., Mach, D. M., and Stewart, M. F.: Global frequency and distribution of lightning as observed from space by the Optical Transient Detector, J. Geophys. Res., 108, doi: 10.1029/2002JD002347, 2003.

Cooper, O. R., Forster, C., Parrish, D., Trainer, M., Dunlea, E., Ryerson, T., Hübler, G., Fehsenfeld, F., Nicks, D., Holloway, J., de Gouw, J., Warneke, C., Roberts, J. M., Flocke, F., and Moody, J.: A case study of transpacific warm conveyor belt transport: Influence of merging airstreams on trace gas import to North America, J. Geophys. Res., 109 (D23S08), doi: 10.1029/2003JD003624, 2004.

Cooper, O. R., Stohl, A., Trainer, M., Thompson, A. M., Witte, J. C., Oltmans, S. J., Morris, G., Pickering, K. E., Crawford, J. H., Chen, G., Cohen, R. C., Bertram, T. H., Wooldridge, P., Perring, A., Brune, W. H., Merrill, J., Moody, J. L., Tarasick, D., Ndddlec, P., Forbes, G., Newchurch, M. J., Schmidlin, F. J., Johnson, B. J., Turquety, S., Baughcum, S. L., Ren, X., Fehsenfeld, F. C., Meagher, J. F., Spichtinger, N., Brown, C. C., McKeen, S. A., McDermid, I. S., and Leblanc, T.: Large upper tropospheric ozone enhancements above midlatitude North America during summer: In situ evidence from the IONS and MOZAIC ozone measurement network, J. Geophys. Res., 111 (D24S05), doi:10.1029/2006JD007306, 2006.

Cooper, O. R. et al.: Evidence for a recurring eastern North American upper tropospheric ozone maximum during summer, J. Geophys. Res., 112 (D23306), doi:10.1029/2007JD008910, 2007.

Cooper, O. R. et al.: Increasing springtime ozone mixing ratios in the free troposphere over western North America, Nature, 463, 344-348, 2010.

Evans, M. J. and Jacob, D. J.: Impact of new laboratory studies of $\mathrm{N}_{2} \mathrm{O}_{5}$ hydrolysis on global model budgets of tropospheric nitrogen oxides, ozone and OH, Geophys. Res. Lett., 32 (L09813), doi:10.1029/2005GL022469, 2005.

Fairlie, T. D., Jacob, D. J., and Park, R. J.: The impact of transpacific transport of mineral dust in the United States, Atmos. Environ., 41, 1251-1266, 2007.

Fairlie, T. D., Jacob, D. J., Dibb, J. E., Alexander, B., Avery, M. A., van Donkelaar, A., and Zhang, L.: Impact of mineral dust on nitrate, sulfate, and ozone in transpacific pollution plumes, Atmos. Chem. Phys. Discuss., 9, 24477-24510, doi:10.5194/acpd9-24477-2009, 2009.

Fiore, A. M., Jacob, D. J., Bey, I., Yantosca, R. M., Field, B. D., Fusco, A. C., and Wilkinson, J. G.: Background ozone over the United States in summer: Origin, trend, and contribution to pollution episodes, J. Geophys. Res., 107, doi:10.1029/ 2001JD000982, 2002.

Fiore, A. M. et al.: Multimodel estimates of intercontinental sourcereceptor relationships for ozone pollution, J. Geophys. Res., 114, doi:10.1029/2008JD010816, 2009.
Fisher, J. A. et al.: Source attribution and interannual variability of Arctic pollution in spring constrained by aircraft (ARCTAS, ARCPAC) and satellite (AIRS) observations of carbon monoxide, Atmos. Chem. Phys., 10, 977-996, doi:10.5194/acp-10-9772010, 2010.

Fu, T.-M., Jacob, D. J., Palmer, P. I., Chance, K., Wang, Y. X., Barletta, B., Blake, D. R., Stanton, J. C., and Pilling, M. J.: Spacebased formaldehyde measurements as constraints on volatile organic compound emissions in East and South Asia, J. Geophys. Res., 112 (D06312), doi:10.1029/2006JD007853, 2007.

Gong, S. L. and Barrie, L. A.: Other heavy metals in the Arctic atmosphere, in: Sources, Occurences, Trends, and Pathways in the Physical Environment, Canadian Arctic Contaminants Assessment Report (CACAR) II, edited by Bidleman, T., MacDonald, R., and Stow, J., pp. 148-152, Indian and Northern Affairs Canada, Ottawa, Ontario, Canada, 2003.

Guerova, G., Bey, I., Attié, J.-L., Martin, R. V., Cui, J., and Sprenger, M.: Impact of transatlantic transport episodes on summertime ozone in Europe, Atmos. Chem. Phys., 6, 2057-2072, doi:10.5194/acp-6-2057-2006, 2006.

Heald, C. L., Jacob, D. J., Fiore, A. M., Emmons, L. K., Gille, J. C., Deeter, M. N., Warner, J., Edwards, D. P., Crawford, J. H., Hamlin, A. J., Sachse, G. W., Browell, E. V., Avery, M. A., Vay, S. A., Westberg, D. J., Blake, D. R., Singh, H. B., Sandholm, S. T., Talbot, R. W., and Fuelberg, H. E.: Asian outflow and transPacific transport of carbon monoxide and ozone pollution: An integrated satellite, aircraft, and model perspective, J. Geophys. Res., 108, doi:10.1029/2003JD003507, 2003.

Heald, C. L., Jacob, D. J., Park, R. J., Alexander, B., Fairlie, T. D., Yantosca, R. M., and Chu, D. A.: Transpacific transport of Asian anthropogenic aerosols and its impact on surface air quality in the United States, J. Geophys. Res., 111 (D14310), doi:10.1029/ 2005JD006847, 2006.

Holzer, M. and Hall, T. M.: Low-level transpacific transport, J. Geophys. Res., 112 (D09103), doi:10.1029/JD007828, 2007.

Hudman, R. C., Jacob, D. J., Cooper, O. R., Evans, M. J., Heald, C. L., Park, R. J., Fehsenfeld, F., Flocke, F., Holloway, J., Hübler, G., Kita, K., Koike, M., Kondo, Y., Neuman, A., Nowak, J., Oltmans, S., Parrish, D., Roberts, J. M., and Ryerson, T.: Ozone production in transpacific Asian pollution plumes and implications for ozone air quality in California, J. Geophys. Res., 109 (D23S10), doi:10.1029/2004JD004974, 2004.

Hudman, R. C., Jacob, D. J., Turquety, S., Leibensperger, E. M., Murray, L. T., Wu, S., Gilliland, A. B., Avery, M., Bertram, T. H., Brune, W., Cohen, R. C., Dibb, J. E., Flocke, F. M., Fried, A., Holloway, J., Neuman, J. A., Orville, R., Perring, A., Ren, X., Sachse, G. W., Singh, H. B., Swanson, A., and Wooldridge, P. J.: Surface and lightning sources of nitrogen oxides over the United States: magnitudes, chemical evolution, and outflow, J. Geophys. Res., 112 (D12S05), doi:10.1029/2006JD007912, 2007.

Hudman, R. C. et al.: North American influence on tropospheric ozone and the effects of recent emission reductions: constraints from ICARTT observations, J. Geophys. Res., 114 (D07302), doi:10.1029/2008JD010126, 2009.

Huntrieser, H., Schumann, U., Schlager, H., Höller, H., Giez, A., Betz, H.-D., Brunner, D., Forster, C., Jr., O. P., and Calheiros, R.: Lightning activity in Brazilian thunderstorms during TROCCINOX: implications for $\mathrm{NO}_{\mathrm{x}}$ production, Atmos. Chem. Phys., 8, 921-953, doi:10.5194/acp-8-921-2008, 2008. 
Jacob, D. J.: Heterogeneous chemistry and tropospheric ozone, Atmos. Environ., 34, 2131-2159, 2000.

Jacob, D. J., Logan, J. A., and Murti, P. P.: Effect of rising Asian emissions on surface ozone in the United States, Geophys. Res. Lett., 26, 2175-2178, 1999.

Jaeglé, L., Steinberger, L., Martin, R. V., and Chance, K.: Global partitioning of $\mathrm{NO}_{\mathrm{x}}$ sources using satellite observations: Relative roles of fossil fuel combustion, biomass burning and soil emissions, Faraday Discussions, 130, 407-423, 2005.

Kaynak, B., Hu, Y., Martin, R. V., Russell, A. G., Choi, Y., and Wang, Y.: The effect of lightning $\mathrm{NO}_{\mathrm{x}}$ production on surface ozone in the continental United States, Atmos. Chem. Phys., 8, 5151-5159, doi:10.5194/acp-8-5151-2008, 2008.

Kleb, M. M., Chen, G., et al.: An overview of measurement comparisons from the INTEX-B/MILAGRO airborne field campaign, Atmos. Meas. Tech. Discuss., 3, doi:10.5194/ amtd-3-2275-2010, 2010.

Koike, M., Kondo, Y., Kita, K., Takegawa, N., Masui, Y., Miyazaki, Y., Ko, M. W., Weinheimer, A. J., Flocke, F., Weber, R. J., Thornton, D. C., Sachse, G. W., Vay, S. A., Blake, D. R., Streets, D. G., Eisele, F. L., Sandholm, S. T., Singh, H. B., and Talbot, R. W.: Export of anthropogenic reactive nitrogen and sulfur compounds from the East Asia region in spring, J. Geophys. Res., 108, doi: 10.1029/2002JD003284, 2003.

Konovalov, I. B., Beekman, M., Richter, A., and Burrows, J. P.: Inverse modelling of the spatial distribution of $\mathrm{NO}_{\mathrm{x}}$ emissions on a continental scale using satellite data, Atmos. Chem. Phys., 6, 1747-1770, doi:10.5194/acp-6-1747-2006, 2006.

Lamsal, L. N., Martin, R. V., van Donkelaar, A., Celarier, E. A., Boersma, R. K., Dirksen, R., Luo, C., and Wang, Y.: Indirect validation of tropospheric nitrogen dioxide retrieved from the OMI satellite instrument: insight into the seasonal variation of nitrogen oxides at northern midlatitudes, J. Geophys. Res., 115 (D05302), doi:10.1029/2009JD013351, 2010a.

Lamsal, L. N., Martin, R. V., et al.: Application of satellite observations for timely updates to bottom-up NOx emission inventories, Geophys. Res. Lett., in preparation, 2010b.

Leaitch, W. R. et al.: Evidence for Asian dust effects from aerosol plume measurements during INTEX-B 2006 near Whistler, BC, Atmos. Chem. Phys., 9, 3523-3546, doi:10.5194/acp-9-35232009, 2009.

Lelieveld, J. and Dentener, F. J.: What controls tropospheric ozone?, J. Geophys. Res., 105 (D23), 3531-3552, 2000.

Levelt, P. F., van den Oord, G. H. J., Dobber, M. R., Malkki, A., Huib, V., de Vries, J., Stammes, P., Lundell, J. O. V., and Saari, H.: The Ozone Monitoring Instrument, IEEE Transactions on Geoscience and Remote Sensing, 44 (5), 1093-1101, doi:10.1109/TGRS.2006.872333, 2006.

Li, Q., Jacob, D. J., Munger, J. W., Yantosca, R. M., and Parrish, D. D.: Export of $\mathrm{NO}_{\mathrm{y}}$ from the North American boundary layer: Reconciling aircraft observations and global model budgets, J. Geophys. Res., 109 (D02313), doi:10.1029/2003JD004086, 2004.

Li, Q., Jiang, J. H., Wu, D. L., Read, W. G., Livesey, N. J., Waters, J. W., Zhang, Y., Wang, B., Filipiak, M. J., Davis, C. P., Turquety, S., Wu, S., Park, R. J., Yantosca, R. M., and Jacob, D. J.: Convective outflow of South Asian pollution: A global CTM simulation compared with EOS MLS observations, Geophys. Res. Lett., 32 (L14826), doi:10.1029/2005GL022762, 2005.
Liang, Q., Jaeglé, L., and Wallace, J. M.: Meteorological indices for Asian outflow and transpacific transport on daily to interannual timescales, J. Geophys. Res., 110 (D18308), doi: 10.1029/2005JD005788, 2005.

Lin, J.-T., McElroy, M. B., and Boersma, K. F.: Constraint of anthropogenic NOx emissions in China from different sectors: a new methodology using multiple satellite retrievals, ACP, 10, 63-78, 2010.

Liu, H., Jacob, D. J., Chan, L. Y., Oltmans, S. J., Bey, I., Yantosca, R. M., Harris, J. M., Duncan, B. N., and Martin, R. V.: Sources of tropospheric ozone along the Asian Pacific Rim: An analysis of ozonesonde observations, J. Geophys. Res., 107, doi:10.1029/ 2001JD002005, 2002.

Liu, S. C., Trainer, M., Fehsenfeld, F. C., Parrish, D. D., Williams, E. J., Fahey, D. W., Hübler, G., and Murphy, P. C.: Ozone production in the rural troposphere and implications for regional and global ozone production, J. Geophys. Res., 92, 4191-4207, 1987.

Liu, X., Bhartia, P. K., Chance, K., Spurr, R. J. D., and Kurosu, T. P.: Ozone profile retrievals from the Ozone Monitoring Instrument, Atmos. Chem. Phys., 10, 2521-2537, doi:10.5194/acp-10-25212010, 2010.

Martin, R. V., Jacob, D. J., Logan, J. A., Bey, I., Yantosca, R. M., Staudt, A. C., Li, Q., Fiore, A. M., Duncan, B. N., Liu, H., Ginoux, P., and Thouret, V.: Interpretation of TOMS observations of tropical tropospheric ozone with a global model and in-situ observations, J. Geophys. Res., 107 (D18), doi:10.1029/ 2001JD001480, 2002.

Martin, R. V., Jacob, D. J., Chance, K. V., Kurosu, T. P., Palmer, P. I., and Evans, M. J.: Global inventory of nitrogen oxide emissions constrained by space-based observations of $\mathrm{NO}_{2}$ columns, J. Geophys. Res., 108 (D17), doi:10.1029/ 2003JD003453, 2003a.

Martin, R. V., Jacob, D. J., Yantosca, R. M., Chin, M., and Ginoux, P.: Global and Regional Decreases in Tropospheric Oxidants from Photochemical Effects of Aerosols, J. Geophys. Res., 108, doi:10.1029/2002JD002622, 2003b.

Martin, R. V., Sioris, C. E., Chance, K., Ryerson, T. B., Bertram, T. H., Wooldridge, P. J., Cohen, R. C., Neuman, J. A., Swanson, A., and Flocke, F. M.: Evaluation of space-based constraints on global nitrogen oxide emissions with regional aircraft measurements over and downwind of eastern North America, J. Geophys. Res., 111 (D15308), doi:10.1029/2005JD006680, 2006.

Martin, R. V., Sauvage, B., Folkins, I., Sioris, C. E., Boone, C., Bernath, P., and Ziemke, J.: Space-based constraints on the production of nitric oxide by lightning, J. Geophys. Res., 112 (D9), doi:10.1029/2006JD007831, 2007.

McKendry, I. G., Hacker, J. P., Stull, R., Sakiyama, S., Mignacca, D., and Reid, K.: Long-range transport of Asian dust to the Lower Fraser Valley, British Columbia, Canada, J. Geophys. Res., 106 (D16), 18 361-18 370, 2001.

McLinden, C. A., Olsen, S. C., Hannegan, B. J., Wild, O., Prather, M. J., and Sundet, J.: Stratospheric Ozone in 3-D Models: A simple chemistry and the cross-tropopause flux, J. Geophys. Res., 105 (D11), 14 653-14 665, 2000.

Miyazaki, Y., Kondo, Y., Koike, M., Fuelberg, H. E., Kiley, C. M., Kita, K., Takegawa, N., Sachse, G. W., Flocke, F., Weinheimer, A. J., Singh, H. B., Eisele, F. L., Zondlo, M., Talbot, R. W., Sandholm, S. T., Avery, M. A., and Blake, D. R.: Synoptic-scale transport of reactive nitrogen over the western Pacific in spring, 
J. Geophys. Res., 108, doi:10.1029/2002JD003248, 2003.

Moxim, W. J., Levy, II, H., and Kasibhatla, P. S.: Simulated global tropospheric PAN: Its transport and impact on $\mathrm{NO}_{\mathrm{x}}, \mathrm{J}$. Geophys. Res., 101, 12 621-12 638, 1996.

Müller, J.-F. and Stavrakou, T.: Inversion of $\mathrm{CO}$ and $\mathrm{NO}_{\mathrm{x}}$ emissions using the adjoint of the IMAGES model, Atmos. Chem. Phys., 5, 1157-1186, doi:10.5194/acp-5-1157-2005, 2005.

Nam, J., Wang, Y., Luo, C., and Chu, D.: Trans-Pacific transport of Asian dust and CO: accumulation of biomass burning $\mathrm{CO}$ in the subtropics and dipole structure of transport, Atmos. Chem. Phys., 10, 3297-3308, doi:10.5194/acp-10-3297-2010, 2010.

Ott, L. E., Pickering, K. E., Stenchikov, G. L., Huntrieser, H., and Schumann, U.: Effects of lightning $\mathrm{NO}_{\mathrm{x}}$ production during the 21 July European Lightning Nitrogen Oxides Project storm studied with a three-dimensional cloud-scale chemical transport model, J. Geophys. Res., 112 (D05307), doi:10.1029/ 2006JD007365, 2007.

Palmer, P. I., Jacob, D. J., Fiore, A. M., Martin, R. V., Chance, K., and Kurosu, T. P.: Mapping isoprene emissions over North America using formaldehyde column observations from space, J. Geophys. Res., 108 (D6), doi:10.1029/2002JD002153, 2003.

Park, R. J., Jacob, D. J., Field, B. D., and Yantosca, R. M.: Natural and transboundary pollution influences on sulfate-nitrateammonium aerosols in the United States: Implications for policy, J. Geophys. Res., 109 (D15204), doi:10.1029/2003JD004473, 2004.

Park, R. J., Jacob, D. J., Kumar, N., and Yantosca, R. M.: Regional visibility statistics in the United States: Natural and transboundary pollution influences, and implications for the Regional Haze Rule, Atmos. Environ., 40 (28), 5405-5423, 2006.

Parrish, D. D., Hahn, C. J., Williams, E. J., Norton, R. B., Fehsenfeld, F. C., Singh, H. B., Shetter, J. D., Gandrud, B. W., and Ridley, B. A.: Indications of Photochemical Histories of Pacific Air Masses From Measurements of Atmospheric Trace Species at Point Arena, California, J. Geophys. Res., 97 (D14), 15 883$15901,1992$.

Parrish, D. D., Dunlea, E. J., Atlas, E. L., Schauffler, S., Donnelly, S., Stroud, V., Goldstein, A. H., Millet, D. B., McKay, M., Jaffe, D. A., Price, H. U., Hess, P. G., Flocke, F., and Roberts, J. M.: Changes in the photochemical environment of the temperate North Pacific troposphere in response to increased Asian emissions, J. Geophys. Res., 109 (D23S18), doi: 10.1029/2004JD004978, 2004.

Parrish, D. D., Millet, D. B., and Goldstein, A. H.: Increasing ozone in marine boundary layer inflow at the west coasts of North America and Europe, Atmos. Chem. Phys., 9, 1303-1323, doi:10.5194/acp-9-1303-2009, 2009.

Pickering, K. E., Wang, Y., Tao, W.-K., Price, C., and Müller, J.F.: Vertical distributions of lightning $\mathrm{NO}_{\mathrm{x}}$ for use in regional and global chemical transport models, J. Geophys. Res., 103, 31203 $31216,1998$.

Price, C. and Rind, D.: A simple lightning parametrization for calculating global lightning distributions, J. Geophys. Res., 97, 9919-9933, 1992.

Rastigeyev, Y., Park, R., Brenner, M. P., and Jacob, D. J.: Resolving intercontinental pollution plumes in global models of atmospheric transport, J. Geophys. Res., 115 (D02302), doi: 10.1029/2009JD012568, 2010.

Richter, A., Burrows, J. P., Nüß, H., Granier, C., and Niemeier, U.:
Increase in tropospheric nitrogen dioxide over China observed from space, Nature, 437, 129-132, 2005.

Roberts, J. M., Fehsenfeld, F. C., Liu, S. C., Bollinger, M. J., Hahn, C., Albritton, D. L., and Sievers, R. E.: Measurements of aromatic hydrocarbon ratios and $\mathrm{NO}_{\mathrm{x}}$ concentration in the rural troposphere: Observation of air mass photochemical aging and $\mathrm{NO}_{\mathrm{x}}$ removal, Atmos. Environ., 18, 2421-2432, 1984.

Sauvage, B., Martin, R. V., van Donkelaar, A., and Ziemke, J. R.: Quantification of the factors controlling tropical tropospheric ozone and the South Atlantic maximum, J. Geophys. Res., 112 (D11309), doi:10.1029/2006JD008008, 2007.

Singh, H. B., Brune, W. H., Crawford, J. H., Flocke, F., and Jacob, D. J.: Chemistry and transport over the Gulf of Mexico and the Pacific: spring 2006 INTEX-B campaign overview and first results, Atmos. Chem. Phys., 9, 2301-2318, doi:10.5194/acp-92301-2009, 2009.

Streets, D. G., Bond, T. C., Carmichael, G. R., Fernandes, S. D., Fu, Q., He, D., Klimont, Z., Nelson, S. M., Tsai, N. Y., Wang, M. Q., Woo, J.-H., and Yarber, K. F.: An inventory of gaseous and primary aerosol emissions in Asia in the year 2000, J. Geophys. Res., 108 (D21), doi:10.1029/2002JD003093, 2003.

Streets, D. G., Zhang, Q., Wang, L., He, K., Hao, J., Wu, Y., Tang, Y., and Carmichael, G. R.: Revisiting China's CO emissions after TRACE-P: Synthesis of inventories, atmospheric modeling, and observations, J. Geophys. Res., 111, doi:10.1029/ 2006JD007118, 2006.

Talbot, R., Dibb, J., Scheuer, E., Seid, G., Russo, R., Sandholm, S., Tan, D., Singh, H., Blake, D., Blake, N., Atlas, E., Sasche, G., Jordan, C., and Avery, M.: Reactive nitrogen in Asian continental outflow over the western Pacific: Results from the NASA Transport and Chemical Evolution over the Pacific (TRACE-P) airborne mission, J. Geophys. Res., 108, doi: 10.1029/2002JD003129, 2003.

Thompson, A. M. et al.: Intercontinental Transport Experiment Ozonesonde Network Study (IONS, 2004): 2. Tropospheric Ozone Budgets and Variability over Northeastern North America, J. Geophys. Res., 112 (D12S13), doi:10.1029/ 2006JD007670, 2007.

Thompson, A. M. et al.: Tropospheric ozone sources and wave activity over Mexico City and Houston during Milagro/Intercontinental Transport Experiment (INTEX-B) Ozonesonde Network Study, 2006 (IONS-06), Atmos. Chem. Phys., 8, 5113-5126, doi:10.5194/acp-8-5113-2008, 2008.

van Donkelaar, A., Martin, R. V., Leaitch, W. R., Macdonald, A. M., Walker, T. W., Streets, D. G., Zhang, Q., Dunlea, E., Jimenez, J. L., Huey, G., Weber, R., and Andreae, M. O.: Analysis of aircraft and satellite measurements from the Intercontinental Chemical Transport Experiment (INTEX-B) to quantify long-range transport of East Asian sulfur to Canada, Atmos. Chem. Phys., 8, 2999-3014, doi:10.5194/acp-8-2999-2008, 2008.

van Noije, T. C. P. et al.: Multi-model ensemble simulations of tropospheric NO2 compared with GOME retrievals for the year 2000, Atmos. Chem. Phys., 6, 2943-2979, doi:10.5194/acp-62943-2006, 2006.

Welch, H. E., Muir, D. C. G., Billeck, B. N., Lockhart, W. L., Brunskill, G. J., Kling, H. J., Olsen, M. P., and Lemoine, R. M.: Brown Snow: A Long-Range Transport Event in the Canadian Arctic, Environ. Sci. Technol., 25, 280-286, 1991.

WMO: International meteorological vocabulary, 91 182, Secretariat 
of the World Meteorological Organization, Geneva, pp. xvi, 276, 1966.

Wu, S., Duncan, B. N., Jacob, D. J., Fiore, A. M., and Wild, O.: Chemical nonlinearities in relating intercontinental ozone pollution to anthropogenic emissions, Geophys. Res. Lett., 36, doi: 10.1029/2008GL036607, 2009.

Zhang, L., Jacob, D. J., Boersma, K. F., Jaffe, D. A., Olson, J. R., Bowman, K. W., Worden, J. R., Thompson, A. M., Avery, M. A., Cohen, R. C., Dibb, J. E., Flocke, F. M., Fuelberg, H. E., Huey, L. G., McMillan, W. W., Singh, H. B., and Weinheimer, A. J.: Transpacific transport of ozone pollution and the effect of recent Asian emission increases on air quality in North America: an integrated analysis using satellite, aircraft, ozonesonde, and surface observations, Atmos. Chem. Phys., 8, 6117-6136, doi:10.5194/acp-8-6117-2008, 2008.

Zhang, L., Jacob, D. J., Kopacz, M., et al.: Intercontinental source attribution of ozone pollution at western US sites using an adjoint method, Geophys. Res. Lett., 36 (L11810), doi:10.1029/ 2009GL037950, 2009a.
Zhang, L., Liao, H., and Li, J.: Impact of the Southeast Asian summer monsoon strength on the outflow of aerosols from South Asia, Ann. Geophys., 28, 277-287, doi:10.5194/angeo-28-2772010, 2010.

Zhang, Q., Streets, D. G., He, K., Wang, Y., Richter, A., Burrows, J. P., Uno, I., Jang, C. J., Chen, D., Yao, Z., and Lei, Y.: $\mathrm{NO}_{\mathrm{x}}$ emission trends for China, 1995-2004: The view from the ground and the view from space, J. Geophys. Res., 112 (D22306), doi: 10.1029/2007JD008684, 2007.

Zhang, Q., Streets, D. G., Carmichael, G. R., He, K. B., Huo, H., Kannari, A., Klimont, Z., Park, I. S., Reddy, S., Fu, J. S., Chen, D., Duan, L., Lei, Y., Wang, L. T., and Yao, Z. L.: Asian emissions in 2006 for the NASA INTEX-B mission, Atmos. Chem. Phys., 9, 5131-5153, doi:10.5194/acp-9-5131-2009, 2009b. 